\title{
Salt stress in maize: effects, resistance mechanisms, and management. A review
}

\author{
Muhammad Farooq • Mubshar Hussain • Abdul Wakeel • \\ Kadambot H. M. Siddique
}

Accepted: 14 January 2015 / Published online: 10 February 2015

(C) INRA and Springer-Verlag France 2015

\begin{abstract}
Maize is grown under a wide spectrum of soil and climatic conditions. Maize is moderately sensitive to salt stress; therefore, soil salinity is a serious threat to its production worldwide. Understanding maize response to salt stress and resistance mechanisms and overviewing management options may help to devise strategies for improved maize performance in saline environments. Here, we reviewed the effects, resistance mechanisms, and management of salt stress in maize. Our main conclusions are as follows: (1) germination and stand establishment are more sensitive to salt stress than later developmental stages. (2) High rhizosphere sodium and chloride decrease plant uptake of nitrogen, potassium, calcium, magnesium, and iron. (3) Reduced grain weight and number are responsible for low grain yield in maize under salt stress. Sink limitations and reduced acid invertase activity in developing grains is responsible for poor kernel setting under salt stress. (4) Exclusion of excessive sodium or its compartmentation into vacuoles is an important adaptive strategy for
\end{abstract}

M. Farooq $(\bowtie)$

Department of Agronomy, University of Agriculture,

Faisalabad, Pakistan

e-mail: farooqcp@gmail.com

M. Farooq $\cdot$ K. H. M. Siddique

The UWA Institute of Agriculture, The University of Western

Australia, Crawley, WA 6009, Australia

M. Farooq

College of Food and Agricultural Sciences, King Saud University,

Riyadh 11451, Saudi Arabia

M. Hussain

Department of Agronomy, Bahauddin Zakariya University,

Multan, Pakistan

A. Wakeel

Institute of Soil and Environmental Sciences,

University of Agriculture, Faisalabad, Pakistan maize under salt stress. (5) Apoplastic acidification, required for cell wall extensibility, is an important indicator of salt resistance, but not essential for better maize growth under salt stress. (6) Upregulation of antioxidant defense genes and $\beta$ expansin proteins is important for salt resistance in maize. (7) Arbuscular mycorrhizal fungi improve salt resistance in maize due to better plant nutrient availability. (8) Seed priming is an effective approach for improving maize germination under salt stress. (9) Integration of screening, breeding and ion homeostasis mechanisms into a functional paradigm for the whole plant may help to enhance salt resistance in maize.

Keywords Arbuscular mycorrhizal fungi $\cdot$ Apoplastic acidification - Carbon fixation - Expansion - Ion homeostasis · Plant-growth-promoting rhizobacteria $\cdot$ Osmotic adjustment . Seed priming

Contents

1. Introduction

2. Effects of Salt Stress

2.1. Germination and plant growth

2.2. Mineral uptake and assimilation

2.3. Light harvesting and carbon fixation

2.4. Grain development and yield

3. Resistance Mechanisms

3.1. Osmoregulation and osmoprotection

3.2. Ion homeostasis

3.3. Apoplastic acidification

3.4. Antioxidant defense system

3.5. Hormonal regulations

3.6. Molecular mechanisms

4. Management of Salt Stress

4.1. Selection and breeding approaches 


\subsection{Marker-assisted selection}

4.3. Biotechnology and functional genomics

4.4. Arbuscular mycorrhizal fungi

4.5. Plant-growth-promoting rhizobacteria

4.6. Exogenous application of hormones and osmoprotectants

4.7. Seed priming and nutrient management

5. Conclusions

\section{Introduction}

Soils with excess soluble salts or exchangeable sodium in the root zone are termed salt-affected soils. Owing to limited rainfall and high evapotranspiration demand, coupled with poor soil and water management practices, salt stress has become a serious threat to crop production in arid and semi-arid regions of the world (Flowers and Yeo 1995; Munns 2002). Although the general perception is that salinization only occurs in arid and semi-arid regions, no climatic zone is free from this problem (Rengasamy 2006). More than 800 million hectares of land worldwide is affected by either salinity (397 million hectares) or sodicity (434 million hectares) (FAO 2005; Munns 2005).

High osmotic stress due to low external water potential, ion toxicity by sodium and/or chloride, or imbalanced nutrition due to interference with the uptake and transport of essential nutrients are three potential effects of salt stress on crop growth. The latter may not have an immediate effect because plants have some nutrient reserves which can be remobilized (Flowers and Flowers 2005; Munns et al. 2006). Osmotic stress is linked to ion accumulation in the soil solution, whereas nutritional imbalance and specific ion effects are connected to ion buildup, mainly sodium and chloride, to toxic levels which interferes with the availability of other essential elements such as calcium and potassium (El-Bassiouny and Bekheta 2001; Munns et al. 2006; Hussain et al. 2013). Toxic levels of sodium in plant organs damage biological membranes and subcellular organelles, reducing growth and causing abnormal development before plant mortality (Davenport et al. 2005; Quintero et al. 2007). Several physiological processes such as photosynthesis, respiration, starch metabolism, and nitrogen fixation are also affected under saline conditions leading to losses in crop productivity.

Maize (Zea mays L.) is the third most important cereal crop after rice and wheat and is grown under a wide spectrum of soil and climatic conditions. It is an important $\mathrm{C}_{4}$ plant from the Poaceae family and is moderately sensitive to salt stress (Fig. 1; Maas and Hoffman 1977; Maas et al. 1983; Chinnusamy et al. 2005); nonetheless, wide intraspecific genetic variation for salt resistance exists in maize (Mansour et al. 2005).

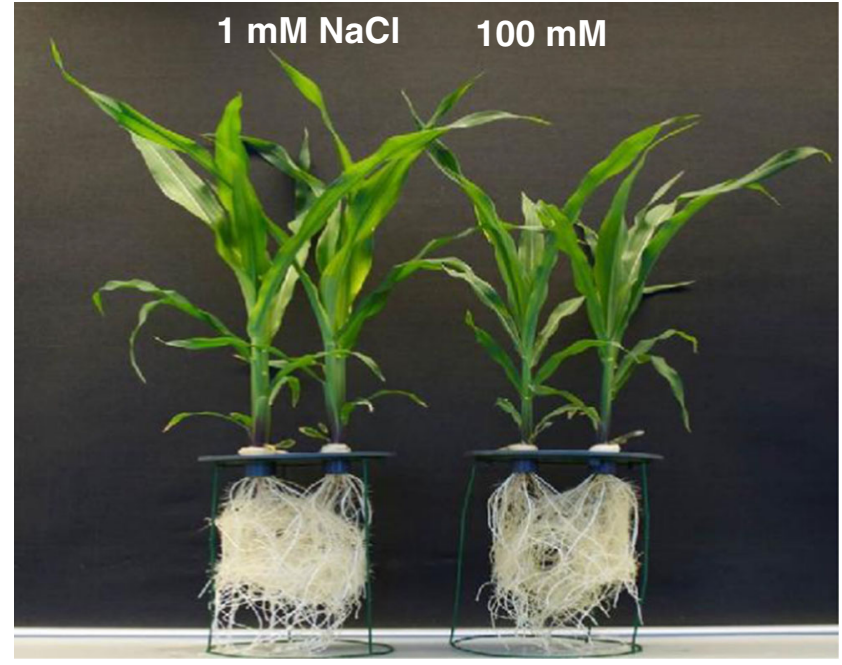

Fig. 1 Effect of salt stress on the vegetative growth of maize (cv. Pioneer 3906) roots and shoots grown hydroponically at 1 and $100 \mathrm{mM} \mathrm{NaCl}$. Treatments were applied 1 week after transplanting. This picture shows the plants 21 days after seed soaking and 1 week after application of salt stress

According to the biphasic model of salinity-induced growth reduction (Munns 1993), osmotic stress during the first phase and ion toxicity during the second phase are responsible for reduced growth in cereals, specifically wheat (Fig. 2). The same model for salinity-induced growth reduction in maize was confirmed by Fortmeier and Schubert (1995), but ion toxicity and the associated growth reduction can occur, to a small extent, in the first phase in maize (Sümer et al. 2004). The sensitivity of maize to salinity is associated with higher accretion of $\mathrm{Na}^{+}$in the leaves (Fortmeier and Schubert 1995).

A saline level of more than $0.25 \mathrm{M} \mathrm{NaCl}$ damages maize plants and may stunt growth and cause severe wilting (Menezes-Benavente et al. 2004). Sodium is the main toxic

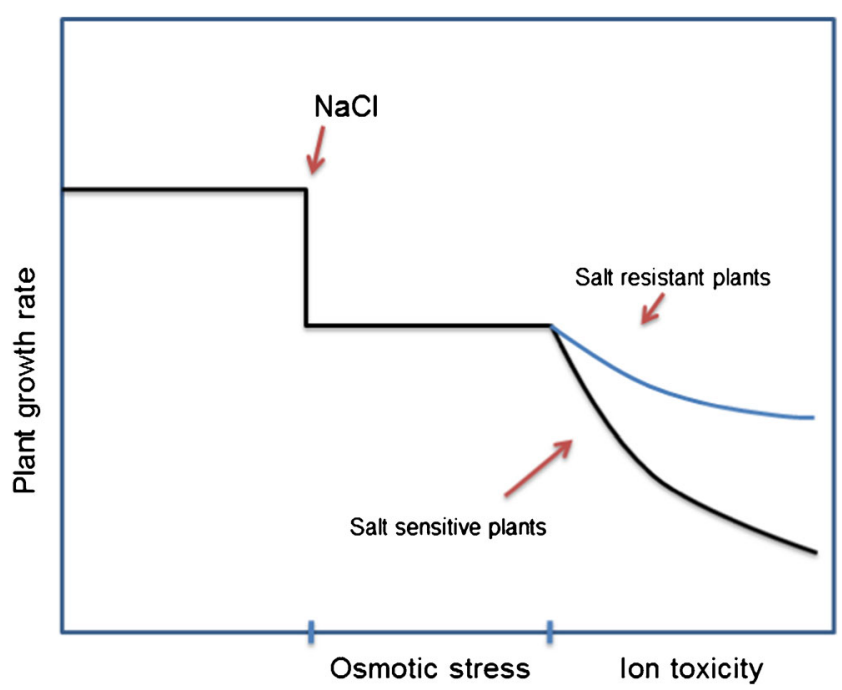

Fig. 2 Biphasic model of salinity-induced growth reduction (modified from Munns 1993) 
ion interfering with potassium uptake and thus disturbs stomatal undulations causing severe water loss and necrosis in maize (Fortmeier and Schubert 1995; Sümer et al. 2004); a reduction in potassium content in the leaf symplast of maize has been reported under saline conditions (Shahzad et al. 2012). Moreover, salt stress also induces oxidative damage to plant cells with overproduction of reactive oxygen species in maize (de Azevedo Neto et al. 2006).

The ability of plants to survive and produce harvestable yields under salt stress is called salt resistance. Salt resistance is a complex phenomenon, and plants manifest a variety of adaptations at subcellular, cellular, and organ levels such as stomatal regulation, ion homeostasis, hormonal balance, activation of the antioxidant defense system, osmotic adjustment, and maintenance of tissue water status to grow successfully under salinity (Neubert et al. 2005; de Azevedo Neto et al. 2006; Hichem et al. 2009; Schubert et al. 2009; Kaya et al. 2010; Jafar et al. 2012). An integrated approach encompassing conventional breeding together with marker-assisted selection, biotechnology, exogenous use of growth regulators/ osmoprotectants, and nutrient management may be needed for successful maize cultivation on salt-affected soils (Eker et al. 2006; Gunes et al. 2007; Janmohammadi et al. 2008; Kaya et al. 2010; Li et al. 2010).

Although several excellent reviews on salt stress in plants are available, there is no comprehensive review on salt stress in maize. In this review, the common morphological, physiological, and molecular responses of maize to salt stress are briefly discussed and some pragmatic options have been proposed on how these responses could be exploited to improve salt resistance in maize.

\section{Effects of salt stress}

Salt stress affects growth and development of maize; however, the response of plants varies with the degree of stress and crop growth stage. Short-term exposure of maize plants to salt stress influences plant growth owing to osmotic stress in the first phase of salt stress (Sümer et al. 2004) without reaching toxic sodium concentrations (Fortmeier and Schubert 1995). The effects of salt stress on growth and productivity, water relations, nutrient uptake and transport, carbon harvesting, grain development, and yield of maize are briefly discussed below.

\subsection{Germination and plant growth}

Seed germination is the most critical stage in seedling establishment which determines the success of crop production on salt-affected soils. Generally, salt stress during germination delays the start, reduces the rate, and enhances the dispersion of germination events (Ashraf and Foolad 2005; Farsiani and
Ghobadi 2009). It is important to note that germination and early seedling growth are more sensitive to salinity than later developmental stages (Goldsworthy 1994).

Salt stress influences seed germination primarily by sufficiently lowering the osmotic potential of the soil solution to retard water absorption by seeds, by causing sodium and/or chloride toxicity to the embryo or by altering protein synthesis. Hyper-osmotic stress and toxic effects of sodium and chloride ions on germinating seeds in a saline environment may delay or inhibit germination (Hasegawa et al. 2000; KhajeHosseini et al. 2003; Farsiani and Ghobadi 2009). However, in maize, it is sodium toxicity and not chloride toxicity that is the major problem in the second phase of salt stress.

Salinity reduces shoot growth by suppressing leaf initiation and expansion, as well as internode growth, and by accelerating leaf abscission (Rios-Gonzalez et al. 2002; Akram et al. 2010a; Qu et al. 2012). Salt stress rapidly reduces leaf growth rate (Munns 1993) due to a reduction in the number of elongating cells and/or the rate of cell elongation (Szalai and Janda 2009).

As a salt-sensitive crop, shoot growth in maize is strongly inhibited in the first phase of salt stress (Pitann et al. 2009a, b; Szalai and Janda 2009; El Sayed 2011; Wakeel et al. 2011a). De Costa et al. (2007) observed stunted maize growth with dark green leaves without any toxicity symptoms during the first phase of salt stress, owing to impaired extension growth as osmotic adjustment and turgor maintenance were not limiting. Likewise, growth of salt-resistant hybrids proved that it was not turgor but cell wall extensibility which restricted cell extension growth during the first phase of salt stress (Van Volkenburgh and Boyer 1985; Schubert 2009; Schubert et al. 2009).

Although the root is the first organ exposed to salt stress, shoots are more sensitive to salt stress than roots (Munns and Sharp 1993). Salinity promotes suberization of the hypodermis and endodermis, and the Casparian strip develops closer to the root tip than in non-saline roots (Shannon et al. 1994). Salt stress may also displace calcium from plasma membranebinding sites, thus causing membrane leakiness as a primary cellular response to salt stress (Cramer et al. 1988). However, it is interesting to note that if salt stress influences the integrity of the plasma membrane, then the cell wall acidification process, which is partially dependent on adenosine triphosphate-driven outward pumping of protons across the intact plasma membrane, may also be affected (Spanswick 1981). Acidification of the apoplast is the major requirement for increasing cell wall extensibility, which controls extension growth (Hager 2003). The apoplastic $\mathrm{pH}$ increased in salt-sensitive maize genotypes under salt stress which reduced extension growth due to less acidification of the apoplast (Pitann et al. 2009a). Plasma membrane $\mathrm{H}^{+}$ pumping by ATPase in maize leaves is inhibited under salt stress, probably due to the expression of inefficient $\mathrm{H}^{+}$- 
ATPase isoforms (Zörb et al. 2005). In contrast to the saltsensitive maize hybrid Pioneer 3906, the salt-resistant hybrid SR 03 maintained plasma membrane $\mathrm{H}^{+}$pumping and expressed reduced apoplastic pH (Pitann et al. 2009c), a premise for cell wall loosening according to the acid growth theory (Hager 2003). Despite maintaining cell wall acidification, growth of the maize hybrid SR 03 decreased in the first phase of salt stress suggesting that additional factors other than apoplastic $\mathrm{pH}$ limit plant growth (Pitann et al. 2009b). In this regard, cell wall proteins such as expansins are of great interest. Expansins, wall-loosening enzymes located within the apoplast of the elongation zone of leaves (Cosgrove 2000), regulate cell elongation. Their function is acid dependent and may contribute to cell wall loosening below pH 5 (Cosgrove 2000; Uddin et al. 2013). Pitann et al. (2009a) observed a reduction in the $\beta$ expansin protein in a salt-sensitive maize hybrid exposed to salt stress, while the salt-resistant hybrid was less affected. In general, $\beta$-expansins are more numerous and abundantly expressed in maize tissues compared to $\alpha$-expansins (Wu et al. 2001). In conjunction with the evolution of the grass cell wall, $\beta$-expansins in maize have developed specialized functions with a distinct set of matrix polysaccharides and structural proteins (Carpita 1996; Wu et al. 2001).

Assimilate supply to growing tissues is not limiting during the first phase of salt stress (De Costa et al. 2007), suggesting that photosynthesis is not responsible for any growth reduction in maize during this phase. However, salinity-induced changes in the activities of leaf cell walls explain this growth reduction (Geilfus et al. 2010). Apoplastic peroxidase and hydrogen peroxide regulate the biosynthesis of diferulates (Encina and Fry 2005) and diferulate cross-links in the maize cell wall (Lindsay and Fry 2008; Burr and Fry 2009). Transient increases in apoplastic peroxidase lead to termination of segmental elongation (De Souza and MacAdam 1998, 2001). The simultaneous increase in peroxidase activity and phenolics in maize corroborates a role of this enzyme in the oxidation of phenolics (Devi and Prasad 1996). For moderate salt stress, inhibition of lateral shoot development becomes apparent over weeks, which affects reproductive development over months, such as early flowering or reduced floret numbers. During this time, a number of older leaves may die; however, production of younger leaves may continue (Munns and Tester 2008).

In crux, germination and stand establishment are more sensitive to salt stress than later developmental stages. Salt stress, during the germination phase, often delays the start of germination and disperses germination events. Salinity-induced growth reduction in maize is caused by suppressed leaf initiation, expansion, and internode growth and by increased leaf abscission. In maize, suppression of expansion growth by salinity is principally caused by reduced apoplastic acidification and activity of wall-loosening enzymes.

\subsection{Mineral uptake and assimilation}

In salt-affected soils, excessive buildup of sodium and chloride ions in the rhizosphere leads to severe nutritional imbalances in maize due to strong interference of these ions with other essential mineral elements such as potassium, calcium, nitrogen, phosphorus, magnesium, iron, manganese, copper, and zinc (Hasegawa et al. 2000; Karimi et al. 2005; Turan et al. 2010). Generally, salt stress reduces the uptake of nitrogen, potassium, calcium, magnesium, and iron (Karimi et al. 2005; Gunes et al. 2007; Turan et al. 2010; Kaya et al. 2010; Shahzad et al. 2012; Qu et al. 2012; Yasmeen et al. 2013).

For maize, sodium is the principal toxic ion (Fortmeier and Schubert 1995; Sümer et al. 2004) interfering with potassium uptake and transport leading to disturbance in stomatal modulations and causing water loss and necrosis. Competition between potassium and sodium under salt stress severely reduces potassium content in both leaves and roots of maize (Alberico and Cramer 1993; de Azevedo Neto and Tabosa 2000; Kaya et al. 2010) and reduces potassium content by up to $64 \%$ in the symplast of expanding tissues under salt stress (Shahzad et al. 2012). Moreover, salt stress not only reduces potassium uptake rates but, to a greater extent, disturbs potassium translocation from root to shoot tissues in maize leading to lower potassium shoot contents than root contents (Shahzad et al. 2012). Reduced potassium content was observed in maize leaves under salt stress; however, in certain genotypes, no reduction in root potassium content was observed (de Azevedo Neto et al. 2004). Net uptake of potassium is dependent on potassium concentration in the root medium and root potassium status, and inhibition in potassium translocation is usually higher at low potassium contents under salt stress (Botelia et al. 1997).

Increased sodium accumulation also disturbs calcium nutrition (Hu et al. 2007; Kaya et al. 2010; Shahzad et al. 2012) during the first phase of salt stress; calcium transport to the youngest leaves of maize is impaired (Fortmeier and Schubert 1995). Reduced leaf expansion with reduced calcium contents in expanding shoot tissues in maize is due to reduced transport in a saline environment; some calcium is required to uphold cell membrane integrity for proper functioning $(\mathrm{Hu}$ et al. 2007). The high values for sodium/potassium, sodium/calcium, and sodium/magnesium ratios in the total plant and apoplast and symplast of expanding tissues in maize confirm that impaired transport of potassium, calcium, and magnesium by sodium might upset plant metabolism leading to reduced growth under saline conditions (Shahzad et al. 2012). In another study, a substantial rise in sodium contents in ten maize hybrids with increasing salinity levels decreased calcium and potassium contents leading to reduced potassium/sodium and calcium/sodium ratios (Akram et al. 2010a).

Besides potassium and calcium, nitrogen uptake and translocation is severely inhibited under salt stress leading to 
reduced nitrogen contents in different maize tissues (Karimi et al. 2005; Gunes et al. 2007; Gadalla et al. 2007; Turan et al. 2010). A gradual increase in salts in irrigation water substantially reduced shoot and grain nitrogen uptake with the maximum reduction observed at $6 \mathrm{dS} \mathrm{m}^{-1}$ salinity in irrigation water (Gadalla et al. 2007). Negative effects of salinity on potassium, calcium, and magnesium uptake are further aggravated under potassium deficiency. Potassium and magnesium contents in both leaves and roots of maize plants decreased drastically under both potassium-deficient and saline conditions, but the reduction was much higher under combined stresses than individual salt stress or potassium deficiency (Qu et al. 2012). Moreover, salt stress significantly increased both sodium and chloride contents in maize leaves and roots and potassium deficiency further aggravated sodium and chloride accretion in leaves and roots of maize. However, potassium, sodium, magnesium, and chloride contents in leaves were higher than those in roots, but calcium leaf contents were lower than that in roots. The potassium/sodium ratio in leaves and roots decreased with a greater reduction under combined stresses than individual stresses (Qu et al. 2012).

Higher buildup of sodium and chloride concentrations in different plant tissues is the principal reason for nutritional imbalances. Accumulation of sodium and chloride concentrations in different plant tissues increased linearly with increasing electrical conductivity of applied water or salinity levels. At low electrical conductivity of irrigation water, chloride accumulation was more than $\mathrm{Na}^{+}$, but as electrical conductivity increased, sodium accretion was much higher than $\mathrm{Cl}^{-}$in maize, and maize productivity was more sensitive to $\mathrm{Na}^{+}$accretion than chloride (Isla and Aragues 2010).

The sodium concentrations in the leaf apoplast of maize significantly increased with higher sodium supply. The sodium concentration in the leaf apoplast did not reach a high enough concentration to cause the decline in leaf growth under salinity. Apoplastic calcium concentration remained constant, while potassium concentrations increased in the leaf apoplast under salinity (Mühling and Läuchli 2002). In this regard, Fortmeier and Schubert (1995) reported the relationship between high sodium in older leaves of maize and the death of respective leaves. Sodium accumulation in leaves, particularly in the leaf apoplast, may be responsible for sodium toxicity in leaves (Volkmar et al. 1998).

In conclusion, high sodium and chloride ions, due to salinity, in the rhizosphere decrease plant uptake of nitrogen, potassium, calcium, magnesium, and iron and thus cause severe nutritional imbalances in maize.

\subsection{Light harvesting and carbon fixation}

Photosynthesis is the most important process by which green plants convert solar energy into chemical energy in the form of organic compounds synthesized by fixation of atmospheric carbon dioxide. Carbon fixation in maize is very sensitive to salt stress (Omoto et al. 2012). Both stomatal and nonstomatal limitations and their combination are associated with salinity-induced reductions in maize photosynthesis (Gong et al. 2011). Reduced stomatal conductance, impaired activities of carbon fixation enzymes, reduced photosynthetic pigments, and destruction of photosynthetic apparatus are among the key factors limiting carbon fixation capacity of maize plants under salt stress (Kaya et al. 2010; Gong et al. 2011; Omoto et al. 2012; Qu et al. 2012).

Total photosynthesis decreases due to inhibited leaf development and expansion, as well as early leaf abscission, and as salt stress is prolonged, ion toxicity, membrane disruption, and complete stomatal closure become the prime factors responsible for photosynthetic inhibition (Fig. 3). Munns and Tester (2008) identified the reduction in stomatal aperture as the most dramatic and readily measurable whole-plant response to salinity and also concluded that the osmotic effect of salt outside the roots induces stomatal responses. Salt stress affects stomatal conductance immediately due to perturbed water relations and shortly afterward due to the local synthesis of abscisic acid.

As a $\mathrm{C}_{4}$ plant, maize uses NADP-malic enzyme-type photosynthesis (Omoto et al. 2012), and these plants fix atmospheric carbon dioxide principally into oxaloacetate through phosphoenolpyruvate carboxylase in mesophyll cells. Oxaloacetate is then transported to mesophyll cell chloroplasts and reduced to malate by the NADP-dependent malate dehydrogenase enzyme. Malate is then shifted to bundle sheath cells of chloroplasts and decarboxylated by NADP-malic enzyme to provide carbon dioxide and reducing power. This carbon dioxide is fixed by ribulose-1,5-bisphosphate carboxylase/oxygenase (Rubisco) via the Calvin cycle as per $\mathrm{C}_{3}$ plants. In that way, higher carbon dioxide contents near Rubisco in the bundle sheath cells restrain oxygenase activity and help to improve photosynthesis compared with $\mathrm{C}_{3}$ plants at the expense of reduced photorespiration (Kanai and Edwards 1999). Activities of $C_{4}$ photosynthetic enzymes like pyruvate orthophosphate dikinase, phosphoenolpyruvate carboxylase, NADP-dependent malate dehydrogenase, and NAD-dependent malate dehydrogenase tend to increase under salt stress in maize even though the structure of mesophyll cell chloroplasts is damaged (Omoto et al. 2012). In contrast, in bundle sheath cells, activities of NADP-malic enzyme and Rubisco decrease without any visual symptoms of damage to chloroplasts in bundle sheath cells. Moreover, pyruvate orthophosphate dikinase protein content increases, but phosphoenolpyruvate carboxylase protein content decreases in maize due to salinity (Omoto et al. 2012). Gas exchange analysis confirmed that reductions in net photosynthetic rate are connected with the limited availability of intercellular carbon dioxide due to reduced rates of transpiration and stomatal conductance in salt-treated maize plants. Furthermore, 


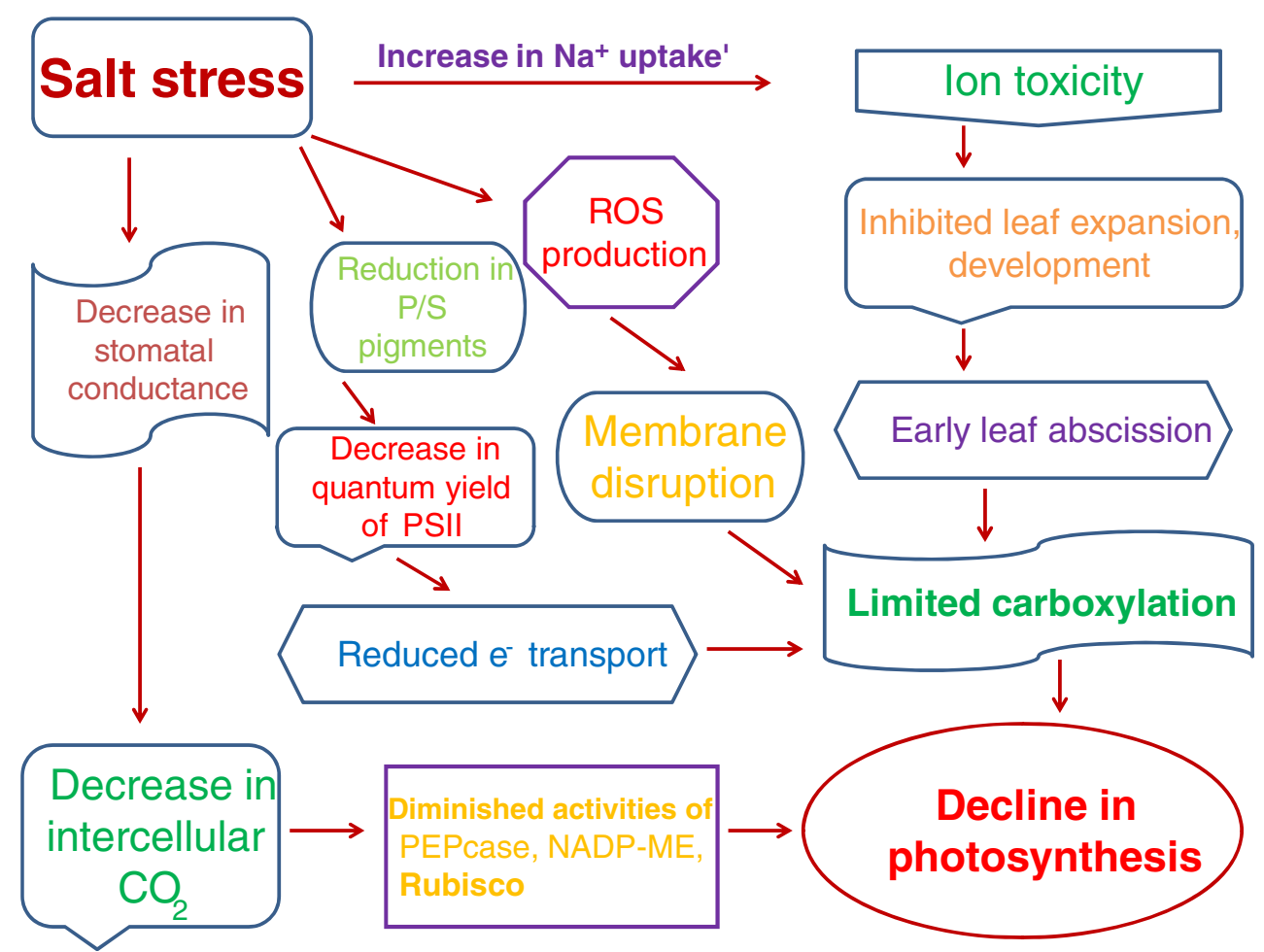

Fig. 3 Possible mechanism in which photosynthesis is reduced under salt stress. Salt stress disturbs the balance between production of reactive oxygen species (ROS) and antioxidant defense causing accumulation of reactive oxygen species, which induces oxidative stress. Increase in tissue $\mathrm{Na}^{+}$causes ion toxicity, which decreases the leaf growth, and results in early leaf abscission, which reduces the carboxylation. Salt stress limits

reductions of 40,89 , and $81 \%$ in the photosynthetic metabolites malate, pyruvate, and starch, respectively, were associated with reduced gas exchange under saline environments. Reduced gas exchange, as a consequence of reduced stomatal conductance and decreased enzyme activities of bundle sheath cells, was responsible for reduced photosynthetic activity in maize under salinity stress (Omoto et al. 2012). Gong et al. (2011) also reported a reduction in both transpiration and net photosynthesis rates due to limited carbon dioxide uptake under salt stress.

A reduction in photosynthetic pigments such as chlorophylls $\mathrm{a}$ and $\mathrm{b}$ and carotenoids is also associated with a decline in the net photosynthesis rate in maize under salt stress (El Sayed 2011; Qu et al. 2012). Cha-um and Kirdmanee (2009) observed a linear reduction in chlorophylls a and b, total chlorophyll, and carotenoid contents in maize with increased salt stress. Moreover, the maximum quantum and photon yield of photosystem II and net photosynthetic rate also decreased due to degradation of chlorophyll and carotenoid contents.

An impaired potassium/sodium ratio, due to increased sodium uptake in maize, affects the bioenergetic processes of photosynthesis under salt stress, and these effects are further aggravated under potassium deficiency. Plant growth, photosynthesis due to a decline in activities of ribulose-1,5-bisphosphate carboxylase/oxygenase (Rubisco), phosphoenolpyruvate carboxylase (PEPCase), and NADP-malic enzyme (NADP-ME). Moreover, noncyclic electron transport is downregulated to match the reduced requirements of reduced (nicotinamide adenine dinucleotide phosphate) production and thus reduces adenosine triphosphate synthesis

chlorophyll and carotenoid contents, potassium and magnesium uptake, photochemical efficiency and the quantum yield of photosystem II, non-photochemical and photochemical photosystem II, and electron transport rates in photosystems I and II of maize plants decreased under salt stress ( $\mathrm{Qu}$ et al. 2012). Moreover, accumulation of sodium and chloride, and the quantum yield of energy dissipation of photosystems I and II in maize leaves increased under salt stress. Salt stress and potassium deficiency impaired the light reaction pathways of photosystems I and II in maize seedlings with a greater reduction in photosystem II than photosystem I (Qu et al. 2012). Likewise, according to Gong et al. (2011), the combination of salt stress and potassium deficiency impacted photosynthesis differently than each individual stress, enhancing oxidative damage and inhibiting maize growth.

To summarize, stomatal and non-stomatal limitations and their combination are associated with salinity-induced reductions in photosynthesis in maize. Stomatal limitations cause reductions in intercellular carbon dioxide, whereas the salinity-induced oxidative damages - reduced canopy size, reduced photosynthetic pigments, and reduced activity of certain photosynthetic enzymes - are the major nonstomatal constraints. 


\subsection{Grain development and yield}

Grain weight and number are important indicators for appraising final grain yield of cereals (Farooq et al. 2011, 2014). Salt stress in maize, during the reproductive phase, decreases grain weight (Abdullah et al. 2001; Kaya et al. 2013) and number (Abdullah et al. 2001; Schubert et al. 2009; Kaya et al. 2013), resulting in substantial reductions in grain yield (Abdullah et al. 2001; Schubert et al. 2009; Kaya et al. 2013). Salinityinduced reductions in photosynthesis and sink limitations are the major causes of poor kernel setting and reduced grain number (Hiyane et al. 2010; Schubert 2011). In this regard, Hutsch et al. (2014) opined that sink limitation rather than decline in photo-assimilation is the primary cause of poor kernel setting and reduced grain number under salt stress. Moreover, the reduction in acid invertase activity in developing maize grains is responsible for poor kernel setting under salt stress. Acid invertase is directly linked to sink strength, and any reduction in its activity will limit grain number in maize owing to accelerated kernel abortion (Hutsch et al. 2014). However, salinity-induced reductions in assimilate translocation, from source to developing grains, are also responsible for poor grain setting and filling and ultimately grain yield (Lohaus et al. 2000).

In conclusion, reduced grain weight and number are responsible for low grain yield of maize under salt stress. Sink limitation and reduced acid invertase activity in developing maize grains are responsible for poor kernel setting and reduced grain numbers under salt stress.

\section{Resistance mechanisms}

Maize plants undergo a variety of adaptations at subcellular, cellular, and organ levels to grow successfully under salinity. Salt resistance is a complex phenomenon; maize plants manifest several adaptations such as stomatal regulation, changes in hormonal balance, activation of antioxidant defense system, osmotic adjustment, maintenance of tissue water contents, and various mechanisms of toxic ion exclusion under salt stress. A brief summary of these salt resistance mechanisms at various levels in maize plants is described below.

\subsection{Osmoregulation and osmoprotection}

Osmotic adjustment or osmoregulation is the key adaptation of plants at the cellular level to minimize the effects of salinity-induced drought stress, especially during the first phase of salt stress. Osmoregulation is primarily met with the accretion of organic and inorganic solutes under salinity and/or drought to lower water potential without lessening actual water contents (Serraj and Sinclair 2002). Soluble sugars, sugar alcohols, proline, glycine betaine, organic acids, and trehalose are among the major osmolytes. Kaya et al. (2010) reported that proline accumulation increases in maize plants experiencing salt stress. At $400 \mathrm{mM} \mathrm{NaCl}$, sweet corn leaves accumulated more than $600 \mu \mathrm{mol} \mathrm{g}^{-1}$ proline (de Azevedo Neto et al. 2004). Likewise, Mansour et al. (2005) reported increased accumulation of both proline and glycine betaine in maize under salt stress.

Soluble amino acid buildup substantially increased in leaves of tested maize genotypes under salt stress with the largest increase $(113 \%)$ in a salt-tolerant genotype (BR5033); BR5033 was the only genotype to also significantly increase amino acid contents in the roots (de Azevedo Neto et al. 2004). However, all of the tested genotypes had the same or lower soluble carbohydrate levels in leaves and roots in saline environments, except for the salt-tolerant maize genotype BR5033 which increased by $14 \%$ in leaves (de Azevedo Neto et al. 2004). Moreover, by comparing salt-stressed plants of both salt-sensitive (BR5011) and salt-tolerant (BR5033) maize genotypes for root amino acid and carbohydrate contents, the salt-tolerant (BR5033) maize genotype accumulated 132 and $122 \%$ more amino acids and carbohydrates, respectively, in roots than the salt-sensitive (BR5011) maize genotype (de Azevedo Neto et al. 2004). In contrast, Hussein et al. (2007) observed reduced amino acid contents such as arginine, lycine, serine, and glutamic acid; no change for glycine; and enhanced levels of proline in response to salt stress in maize. Salt stress also induced polyamine accumulation, but spermidine was absent, possibly due to its fast turnover (Erdei et al. 1996). In crux, osmoregulation helps maize plants to minimize the effects of salinity-induced osmotic stress. Proline and glycine betaine are the major osmolytes responsible for osmoregulation in maize under salt stress.

\subsection{Ion homeostasis}

Physiologically, the exclusion of excessive salt is an adaptive trait of plants to acquire salt resistance. Accumulation of sodium in excessive amounts is highly toxic for maize growth (Fortmeier and Schubert 1995) due to its strong interference with potassium leading to disturbed stomatal regulation. Therefore, exclusion of excessive sodium or its compartmentation into vacuoles through tonoplast hydrogen/sodium antiporters driven by the proton gradient is an important adaptive strategy for plants under salt stress. Through this strategy, maize plants not only evade the cytosol from the toxic effects of excessive sodium and gain tissue resistance for sodium (Neubert et al. 2005), but also significantly lower the osmotic potential which contributes to osmoregulation. In root cells of maize, shifting sodium into vacuoles through the tonoplast appears a viable strategy to minimize sodium transport to developing shoots (Neubert et al. 2005). Likewise, Chen et al. (2007) reported that transgenic maize overexpressing the Oryza sativa sodium/hydrogen antiporter (OsNHXI) gene 
outperformed the wild-type maize at $200 \mathrm{mM} \mathrm{NaCl}$ and accumulated more sodium and potassium in leaves coupled with lower osmotic potential.

Absorption of excessive sodium from xylem by parenchyma cells in xylem to limit sodium translocation to shoots is reported in maize (Yeo et al. 1977). While active sodium efflux from maize roots under salinity was noted, the more efficient sodium-excluding hybrid (Pioneer 3906) did not have higher efflux rates than the less efficient sodium-excluding hybrid (XL 75) (Schubert and Läuchli 1990). Mansour et al. (2005) reported that the salt-sensitive maize cultivar (Trihybrid 321) had higher leaf sodium than the salt-tolerant maize (Giza 2). However, Alberico and Cramer (1993) suggested that salt resistance in maize is not linked to sodium content in shoots but rather that the ability of cells to shift excessive sodium in vacuoles to maintain low sodium concentrations in the cytoplasm seemed more important.

Salt resistance in some maize varieties is linked with higher potassium and lower sodium and chloride fluxes and cytoplasmic contents (Table 1; Hajibagheri et al. 1989) and their ability to rule out sodium and chloride from leaves to sustain a higher potassium/sodium ratio (Cerda et al. 1995). The salt-resistant maize hybrid (BR5033) excluded sodium more efficiently from leaf cell cytoplasm than the salt-sensitive hybrid (BR5011) (de Azevedo Neto et al. 2004). Moreover, shifting sodium and chloride in the stems and/or leaf sheaths to lessen the buildup of toxic ions in more sensitive leaf blades is another adaptive strategy of maize plants in a saline environment (Isla and Aragues 2010).

Under salt stress, maintaining potassium uptake and reducing potassium efflux from cells, and preventing sodium entry and increasing efflux of sodium from cells are common strategies adopted by plants to maintain desirable potassium/ sodium ratios in the cytosol (Wakeel et al. 2011b); resistant maize hybrids have higher potassium/sodium ratios than sensitive ones (Akram et al. 2007). At higher levels of salt stress in a solution culture study, the two tolerant maize hybrids (Pioneer 32B33 and Pioneer 30Y87) of ten hybrids under study maintained the highest potassium and calcium contents resulting in superior potassium/sodium and calcium/sodium ratios and produced more biomass (Akram et al. 2010a). Moreover, salt-tolerant hybrids maintained higher levels of potassium in shoots than sodium while salt-sensitive hybrids accumulated more sodium in shoots, and differential selectivity of plasma membrane may be associated with the sensitivity/resistance of these hybrids (Akram et al. 2010a). According to Mansour et al. (2005), salt stress substantially increased sodium accretion at the expense of potassium and calcium in the salt-resistant maize cultivar (Giza 2) than the salt-sensitive cultivar (Trihybrid 321), while Cramer et al. (1994) reported twice as much sodium accretion in the highbiomass-producing hybrid (Pioneer 3578) than the lowbiomass-producing hybrid (Pioneer 3572) suggesting that maize growth was primarily affected by osmotic factors under salinity.

In conclusion, exclusion of excessive sodium or its compartmentation into vacuoles is an important adaptive strategy for plants under salt stress, which helps maize plants to avoid toxic effects of excessive sodium and lowers the osmotic potential thus contributing to osmoregulation.

\subsection{Apoplastic acidification}

The acidification of cell apoplasts is required for cell wall extensibility (Hager 2003) because lower apoplastic pH is needed to activate the cell-wall-loosening enzymes, expansins (Cosgrove 2000). Poor cell wall acidification leads to impaired growth in maize seedlings during the first phase of salt stress due to inefficient plasma membrane $\mathrm{H}^{+}$-pumping by ATPase, which may be due to changes in gene expression (Zörb et al. 2005). However, the SR maize hybrid SR 03 maintained $\mathrm{H}^{+}$-pumping and decreased apoplastic $\mathrm{pH}$ better than its parent hybrid Pioneer 3906, a prerequisite for cell wall loosening to promote growth under salt stress (Pitann et al. 2009c; Wakeel et al. 2011a). Even though SR 03 had more cell wall acidification, growth decreased during the first phase of salt stress highlighting the possibility that factors other than apoplastic $\mathrm{pH}$ are responsible for limiting cell wall extensibility (Pitann et al. 2009b). Although, maintaining low $\mathrm{pH}$ under salt stress is not a necessary parameter for better growth of maize (Hatzig et al. 2010).

In crux, apoplastic acidification under salt stress, required for cell wall extensibility, is an important indicator of salt resistance; nonetheless, it is not essential for better maize growth under salt stress.
Table 1 Cytosolic/cytoplasmic sodium concentration in different parts of maize under saline conditions

\begin{tabular}{lllll}
\hline Method & $\begin{array}{l}\text { Plant } \\
\text { part }\end{array}$ & $\begin{array}{l}\text { External (sodium) } \\
(\mathrm{mM})\end{array}$ & $\begin{array}{l}\text { Cytosoliccytoplasmic } \\
\text { sodium concentration } \\
\text { or activity (mM) }\end{array}$ & Reference \\
\hline Efflux analysis & Root & 50 & $79-142$ & $\begin{array}{l}\text { Hajibagheri et al. (1989) } \\
\text { X-ray microanalysis }\end{array}$ \\
& Root & 25 & $9-11$ & Schubert and Läuchli (1990) \\
& Root & 100 & $42-138$ & Hajibagheri et al. (1987) \\
& Leaf & 200 & 100 & Hajibagheri et al. (1987) \\
\hline
\end{tabular}




\subsection{Antioxidant defense system}

Salinity-induced osmotic effects alter general metabolic processes and enzymatic activities leading to overgeneration of reactive oxygen species which causes oxidative stress in maize (Menezes-Benavente et al. 2004). Overproduction of reactive oxygen species is highly toxic and damages proteins, lipids, carbohydrates, and deoxyribonucleic acid. Photosystems I and II in chloroplasts and complex I, ubiquinone, and complex III of the electron transport chain in mitochondria are key sites for reactive oxygen species synthesis (Gill and Tuteja 2010). Salinity-induced overgeneration of hydrogen peroxide caused leaf veins in maize to collapse due to leakage into neighboring cells (Menezes-Benavente et al. 2004). Plants have multigenic responses against salt stress that involve both osmotic and ionic homeostasis, as well as cell detoxification, which is primarily met by antioxidant defense mechanisms (Zhu 2001; Mittler 2002; Sairam and Tyagi 2004).

Salinity enhanced the accretion of malondialdehyde (product of lipid peroxidation) in leaves of both salt-tolerant (Arper) and salt-sensitive (Aristo) maize genotypes in a linear fashion with increasing salinity levels (Hichem et al. 2009). Accumulation was more in senescent leaves than mature or young leaves in both genotypes (Hichem et al. 2009). However, the two genotypes behaved differently with higher malondialdehyde contents in Aristo (sensitive) than in Arper (tolerant) due to different antioxidant potentials. The better leaf growth, leaf water content, and membrane stability index observed in salt-tolerant maize (Arper) were associated with higher antioxidant activity with greater accumulation of polyphenols under saline conditions (Hichem et al. 2009). Salt stress enhanced the activities of antioxidant enzymes in maize plants (Rios-Gonzalez et al. 2002) with higher catalase activity in both roots and leaves and higher glutathione reductase and glutathione-S-transferase activity in leaves, and the overall activity of antioxidant enzymes was higher in roots than leaves. Moreover, mature sections of roots had higher superoxide dismutase and peroxidase activities than root tips, and activities were higher in the cortex section than stele of nodal roots which may be due to oversynthesis of free radicals in mature sections of the cortex of maize nodal roots (RiosGonzalez et al. 2002). Activities of superoxide dismutase, ascorbate peroxidase, guaiacol peroxidase, and glutathione reductase increased in leaves of salt-stressed maize, and enhanced enzyme activities were more pronounced in salttolerant maize (BR5033) than in salt-sensitive maize (BR5011) (de Azevedo Neto et al. 2006). Glutathione reductase and catalase activities decreased while ascorbate peroxidase, guaiacol peroxidase, and glutathione reductase activities did not significantly change in the roots of the salt-tolerant cultivar, but activities of all studied enzymes decreased under salinity in the roots of salt-sensitive cultivar (de Azevedo Neto et al. 2006). Catalase, ascorbate peroxidase, and guaiacol peroxidase enzymes in combination with superoxide dismutase had the greatest hydrogen peroxide scavenger activity in both leaves and roots of salt-stressed maize plants, as higher lipid peroxidation was detected only in the leaves of the sensitive genotype (BR5011) under salt stress (de Azevedo Neto et al. 2006).

Likewise, salt stress induced polyamine accumulation in maize (Erdei et al. 1996). For instance, salt stress increased apoplastic spermine and spermidine levels, mainly in the leaf blade elongation zone. Polyamine oxidase activity provides significant production of reactive oxygen species in the apoplast, which contributes to $25-30 \%$ of maize leaf blade elongation (Rodríguez et al. 2009).

In summary, increased activities of enzymatic and nonenzymatic antioxidants help maize plants to maintain growth by scavenging the oxidative damages.

\subsection{Hormonal regulations}

Plant growth and development is governed by the synthesis of hormones with small amounts sufficient to regulate plant growth. Auxins, gibberellins, cytokinins, ethylene, and abscisic acid are the most important phytohormones; among them, the first three are growth promoters while the other two are growth retardants. Maize plants under salt stress make certain modifications to the synthesis of these growth substances. For instance, Younis et al. (2003) observed increased abscisic acid levels at the expense of indole acetic acid (auxins) in maize under salinity stress; this modification may lead to stomatal closure to minimize water loss as a consequence of salinity-induced osmotic stress. In a saline environment, root tips are the first to sense impaired water availability due to the osmotic effect sending a signal to shoots to adjust whole-plant metabolism (Schubert 2009). Therefore, higher abscisic acid accumulation in salt-resistant hybrids than in the salt-sensitive maize hybrid (Pioneer 3906) under salt stress highlighted the importance of abscisic acid accumulation for salt resistance during the first phase of salinity stress (Schubert 2009; Schubert et al. 2009). The reduced sensitivity of leaf growth to increased abscisic acid concentrations under salt stress may be related to a growth-promoting function regulated by abscisic acid during the first phase of salt stress (de Costa et al. 2007).

In conclusion, higher abscisic acid levels in salt-stressed maize helps to minimize water loss and may even regulate growth promotion. Leaf growth sensitivity decreases as abscisic acid levels increase under such conditions.

\subsection{Molecular mechanisms}

Maize plants facing salt stress undergo a variety of adaptive mechanisms at the molecular level to counteract the damaging 
effects of salinity stress. Of these, accumulation or inhibition of several proteins and the upregulation and downregulation of many gene transcripts are important (Zörb et al. 2004; Menezes-Benavente et al. 2004). Expression of antioxidant defense genes is triggered in maize to protect the cells from salinity-induced oxidative damage (Menezes-Benavente et al. 2004). In photosynthesizing shoots of maize, catalase activity increased due to the induction of mRNA accumulation in response to higher reactive oxygen species levels under salt stress (Menezes-Benavente et al. 2004). Likewise, the buildup of superoxide dismutase transcripts increased without any notable change in total superoxide dismutase enzymatic activity or isozyme profiles (Menezes-Benavente et al. 2004). Moreover, Sod1, Sod2, Sod4, Sod4A, and all catalase transcripts were suppressed in maize plants facing high intensity of salt stress (Menezes-Benavente et al. 2004). Inhibition of plasma membrane $\mathrm{H}^{+}$-pumping by ATPase, probably due to increased expression of inefficient $\mathrm{H}^{+}$-ATPase isoforms, has been reported in maize leaves under saline conditions (Zörb et al. 2005; Pitann et al. 2009c).

Maize plants undergo several changes in protein accumulation under salt stress. Maize grown under mild salt stress $(25 \mathrm{mM} \mathrm{NaCl})$ experienced differential regulation in 31 and $45 \%$ of shoot and root proteins, respectively, without any effect on morphology or sodium and chloride uptake, whereas maize plants exposed to high salt stress $(100 \mathrm{mM} \mathrm{NaCl})$ underwent uncontrolled change in more than $80 \%$ of total separated proteins (Zörb et al. 2004). Fourteen proteins upregulated by salt stress were deoxyribonucleic acid-directed: deoxyribonucleic acid polymerase (A1), ribosomal protein $\mathrm{S} 4$ (A2), cytochrome P450-like protein (A3), serine/threonine kinase (A4), adenosine kinase (A5), Rubisco large chain (B6), Rubisco small chain (B7), fructose 1,6-bisphosphate aldolase (B8), glyceraldehyde-3-phosphate dehydrogenase (B9), $\beta$ glucosidase (B10), V-ATPase subunit $\alpha$ (B11), methionine synthase (C12), $S$-adenosyl-methionine synthase (C13), and glutamate-ammonia ligase (C14). Under low salt stress in maize, these 14 proteins belong to three different groups, i.e., (A) proteins involved in protein biosynthesis and modifications by kinases, (B) enzymes of carbon metabolism, and (C) nitrogen metabolism (Zörb et al. 2004).

Considering that cell wall rigidness under unfavorable conditions is crucial for stress adaptation, it is not surprising that expansins are differentially regulated in an organ-specific manner and that salt-sensitive to salt-tolerant cultivars differ in their response to salt stress. For example, six isoforms of expansins were investigated in a resistant and a tolerant maize cultivar which differed in upregulation or downregulation (Geilfus et al. 2010). The alteration/adaptation in cell wall chemical composition may also contribute to salt resistance in maize, as a low accumulation of non-methylated uronic acid in leaf cell walls may contribute to salt resistance in the first phase of salt stress (Uddin et al. 2013).
Salt stress $(100 \mathrm{mM} \mathrm{NaCl})$ reduced root and shoot growth by more than 20 and $50 \%$, respectively (Geilfus et al. 2010); however, total ribonucleic acid content of stressed maize apical parts did not significantly change compared to the controls (Atanassova et al. 1997). As for shoots, the apical ribonucleic acid machinery of monocotyledonous plants such as maize is considered more protected (Aspinall 1986; Barlow 1986; Peterson et al. 1987).

In maize roots, salt stress induced the accumulation of four polypeptides with molecular masses of $61,51,39$, and $29 \mathrm{kDa}$ (Tamas et al. 2001). Rodríguez-Kessler et al. (2006) reported the upregulation of two genes, Zmodc and Zmspds2A, responsible for polyamine and spermidine synthesis under salt stress in maize. Genotypic differences in the relative concentration of six $\beta$-expansin transcripts together with differences in the abundance of $\beta$-expansin protein were observed in response to $\mathrm{NaCl}$ stress. In salt-sensitive Lector, reduced $\beta$-expansin protein expression correlated positively with reduced shoot growth under stress. Downregulation of $Z m \operatorname{Exp} B 2$, $Z m E x p B 6$, and $Z m E x p B 8$ transcripts possibly contributed to the reduced protein abundance. In contrast, maintenance of shoot growth in SR 03 may be related to an unaffected abundance of growth-mediating $\beta$-expansin proteins in shoots. In this regard, the upregulation of $Z m E x p B 2, Z m E x p B 6$, and $Z m E x p B 8$ may sustain the stable expression of $\beta$-expansin protein under salt stress (Geilfus et al. 2010).

In crux, accumulation or inhibition of specific proteins and the upregulation and/or downregulation of many gene transcripts help in salt resistance of maize. In this regard, upregulation of antioxidant defense genes and expression of $\beta$ expansin proteins are important for salt resistance in maize.

\section{Management of salt stress}

The introduction of salt-tolerant genotypes along with accurate site-specific production technology is needed to sustain maize productivity in salt-affected areas. Recent progress in the field of genomics and biotechnology, coupled with conventional breeding approaches, has the potential to introduce transgenic maize cultivars to perform well under stress conditions. Moreover, exogenous application of certain osmoprotectants and growth regulators, nutrient management, and seed invigoration techniques may also be helpful for cost-effective maize production in saline areas.

\subsection{Selection and breeding approaches}

Maize is a highly polymorphic plant due to its cross-pollinated nature with genetic variability in which salinity resistance exists (Paterniani 1990). Therefore, mass screening of maize genotypes is often used to identify salt-tolerant germplasm for breeding programs to develop better-performing genotypes 
for salt-prone areas. Quick screenings for salt resistance on the basis of some agronomic traits during early growth stages of maize are often deemed valuable (Khan et al. 2003; Eker et al. 2006).

Maize is moderately salt-sensitive, but some tolerant genotypes may exist due to lower sodium and chloride cytoplasmic contents and higher potassium cytoplasmic contents (Hajibagheri et al. 1989), and more potential to exclude sodium and chloride from leaves to maintain superior potassium/ sodium ratios (Cerda et al. 1995). For instance, Benes et al. (1996) reported restricted buildup of sodium and chloride in roots due to their ensuing transport to shoots in salt-resistant maize cultivars. Giaveno et al. (2007) confirmed genetic variability among hybrids for germination under salt stress and concluded that traits like seedling weight, growth rate, and photochemical efficiency should be used to screen salttolerant maize hybrids under salt stress.

Significant variation in ion accumulation among 19 maize genotypes under salt stress $(250 \mathrm{mM} \mathrm{NaCl})$ for 6 days prior to harvest was observed by Eker et al. (2006). Salt-tolerant genotypes (based on severity of leaf symptoms) had appreciably lower sodium accumulation in shoots and manifested higher potassium/sodium and calcium/sodium ratios. The most sensitive genotype (C.7993) had four times more sodium accumulation in shoots than the most tolerant genotype (Maverik), suggesting that sodium buildup in shoots is a reliable screening parameter for salt resistance in early growth stages of maize. According to Mansour et al. (2005), sodium accumulation was higher in salt-tolerant Giza 2 than salt-sensitive Trihybrid 321. Higher abscisic acid accumulation in saltresistant hybrids may play a role in osmotic stress resistance under salt stress (De Costa et al. 2007). Cell wall acidification due to improved plasma membrane $\mathrm{H}^{+}$-ATPase activity in the salt-resistant hybrid (SR 03) seemed an important resistance trait; whereas in the sensitive hybrid (Pioneer 3906), $\mathrm{H}^{+}$pumping decreased due to the expression of inefficient $\mathrm{H}^{+}$ATPase isoforms. While osmotic adjustment, turgor, and cell wall acidification were maintained in the newly developed salt-resistant hybrids, cell wall extensibility appeared to limit extension growth (Schubert et al. 2009).

In conclusion, mass screening of maize genotypes for salt resistance may be done on the basis of seedling weight, growth rate, photochemical efficiency, osmotic adjustment, and cell wall acidification.

\subsection{Marker-assisted selection}

A proteomic approach can be used to identify proteins associated with salt resistance in maize for markers in breeding programs to develop salt-tolerant genotypes. For instance, Zörb et al. (2004) observed that 31 and $45 \%$ of shoot and root proteins, respectively, under mild stress $(25 \mathrm{mM} \mathrm{NaCl})$ and more than $80 \%$ of total separated proteins under severe salt stress (100 mM NaCl) experienced differential regulation in maize. In another study, de Azevedo Neto et al. (2004) identified two maize genotypes BR5033 and BR5011 as the most salt-tolerant and salt-sensitive, respectively, from the genotypes under study based on root and shoot dry matter, leaf area, relative growth rate, and net assimilation rate. Moreover, shoot to root dry mass ratio, and leaf sodium and soluble organic solute contents had no clear relationship with salt resistance, but sodium and soluble organic solute accumulations in roots were associated with maize salt resistance. Therefore, sodium and soluble organic solute accumulations in roots can be used as physiological markers to screen maize for salt resistance (de Azevedo Neto et al. 2004).

In crux, use of molecular and physiological markers to select maize genotypes for salt resistance is an attractive approach. Leaf sodium, soluble organic solute accumulation in roots, and expression of specific proteins may help in selecting maize genotypes for salt resistance.

\subsection{Biotechnology and functional genomics}

Transferring one or more genes from one species to another to provoke desired qualitative and quantitative characters is referred to as the transgenic approach. This technique is much faster than conventional breeding and ensures induction of wanted genes without entry of surplus genes from the donor organism (Gosal et al. 2009). Advances in functional genomics and biotechnology have made it possible to recognize salinity-responsive genes to establish plants with better salt resistance through transgenic approaches. The sodium exclusion from cytoplasm to the apoplasts or its compartmentation in vacuoles through plasma membrane or tonoplast sodium/ hydrogen antiporters is an adaptive mechanism to avoid the toxic effects of excess sodium ions in maize plants (Blumwald 2000; Hasegawa et al. 2000). Salt stress enhanced transcription of $Z m N H X$ which may lead to increased tonoplast sodium/hydrogen antiporters in leaves of salt-resistant maize hybrids by sequestering sodium into leaf vacuoles to protect the cytoplasm from sodium toxicity (Pitann et al. 2013). Transgenic maize plants performed better than wild-type plants under saline conditions as a result of higher sodium/ hydrogen exchange rates in tonoplast vesicles (Table 2; Li et al. 2010). The complementary DNA (cDNA) macroarray is an effective tool for studying expression profiles to evaluate similarities and differences in different expression patterns under salt stress. A cDNA macroarray with 190 maize expressed sequence tags induced by water stress was exposed to abscisic acid, high salinity, and cold stress conditions. Abscisic acid upregulated 48 and 111 expressed sequence tags in leaves and roots, respectively, while high salinity stress upregulated 36 and 41 expressed sequence tags in leaves and roots, respectively (Zheng et al. 2006). 
Table 2 Transgenic maize for salt tolerance

\begin{tabular}{|c|c|c|c|c|c|c|}
\hline Gene & Gene product & Source & Cellular role(s) & Parameter studied & Conditions & Reference \\
\hline $\operatorname{AtNHX1}$ & $\begin{array}{l}\text { Vacuolar sodium/ } \\
\text { proton antiporter }\end{array}$ & Arabidopsis & $\begin{array}{l}\text { Sodium vacuolar } \\
\text { sequestration }\end{array}$ & $\begin{array}{l}\text { Improved germination } \\
\text { and increased biomass }\end{array}$ & Field & Yin et al. (2004) \\
\hline$O s N H X 1$ & $\begin{array}{l}\text { Vacuolar sodium/ } \\
\text { proton antiporter }\end{array}$ & Rice & $\begin{array}{l}\text { Sodium vacuolar } \\
\text { sequestration }\end{array}$ & Increased biomass & $\begin{array}{l}\text { Solution culture in } \\
\text { greenhouse }\end{array}$ & Chen et al. 2007) \\
\hline GutD & $\begin{array}{l}\text { Glucitol-6-phosphate } \\
\text { dehydrogenase }\end{array}$ & E. coli & $\begin{array}{l}\text { Synthesis and } \\
\text { accumulation } \\
\text { of sorbitol }\end{array}$ & Increased biomass & $\begin{array}{l}\text { Solution culture in } \\
\text { greenhouse }\end{array}$ & Liu et al. (1999) \\
\hline$B A D H$ & $\begin{array}{l}\text { Betaine aldehyde } \\
\text { dehydrogenase }\end{array}$ & $\begin{array}{l}\text { Suaeda } \\
\quad \text { liaotungensis } \\
\quad \text { Kitag }\end{array}$ & $\begin{array}{l}\text { Synthesis and } \\
\text { accumulation } \\
\text { of glycine betaine }\end{array}$ & $\begin{array}{l}\text { Better survival and } \\
\text { growth under salt } \\
\text { stress }\end{array}$ & Solution culture & Wu et al. (2008) \\
\hline$B A D H$ & $\begin{array}{l}\text { Betaine aldehyde } \\
\text { dehydrogenase }\end{array}$ & Atriplex hortensis & $\begin{array}{l}\text { Synthesis and } \\
\text { accumulation } \\
\text { of glycine betaine }\end{array}$ & $\begin{array}{l}\text { Better survival and } \\
\text { growth under salt } \\
\text { stress }\end{array}$ & $\begin{array}{l}\text { Solution culture in } \\
\text { greenhouse }\end{array}$ & He et al. (1999) \\
\hline AtNHXI & $\begin{array}{l}\text { Vacuolar sodium/ } \\
\text { proton antiporter }\end{array}$ & Arabidopsis & $\begin{array}{l}\text { Sodium vacuolar } \\
\text { sequestration }\end{array}$ & $\begin{array}{l}\text { Improved germination } \\
\text { and increased biomass }\end{array}$ & Field & Li et al. (2010) \\
\hline$B t$ & $\begin{array}{l}\text { Expression of low- } \\
\text { molecular-weight } \\
\text { proteins }\end{array}$ & $\begin{array}{l}\text { Bacillus } \\
\quad \text { thuringiensis }\end{array}$ & $\begin{array}{l}\text { Synthesis of stress- } \\
\text { responsive proteins } \\
\text { with molecular } \\
\text { weights } 298.81 \\
99.82,20.79 \\
\text { and } 19.43 \mathrm{kDa}\end{array}$ & $\begin{array}{l}\text { Better growth and } \\
\text { stability of chlorophyll } \\
\text { pigments }\end{array}$ & $\begin{array}{l}\text { Soil-filled plastic } \\
\text { pots under natural } \\
\text { conditions }\end{array}$ & Beltagi (2008) \\
\hline
\end{tabular}

Likewise, Quan et al. (2004) introduced the betA gene encoding choline dehydrogenase from Escherichia coli in maize inbred line DH4866 to establish transgenic maize with better capacity for glycine betaine biosynthesis from choline under stress conditions. Transgenic maize equipped with the $O$. sativa sodium/hydrogen antiporter $(O s N H X 1)$ gene outperformed and outyielded the wild-type maize at $200 \mathrm{mM} \mathrm{NaCl}$ in greenhouse conditions. Leaves of transgenic maize had higher sodium and potassium contents coupled with lower osmotic potential than those of wildtype maize treated with $100-200 \mathrm{mM} \mathrm{NaCl}$ (Chen et al. 2007). Bt transgenic lines of maize hybrid (YieldGard 2) almost maintained growth when subjected to $0,50,100$, and $150 \mathrm{mM} \mathrm{NaCl}$ salt stress primarily due to higher chlorophyll contents and chlorophyll stability index at all salinity levels (Beltagi 2008).

At $0.4 \% \mathrm{NaCl}$, only $50 \%$ of wild-type seeds germinated, and lower leaves of existing plants withered and upper leaves shriveled, whereas in transgenic maize with the AtNHX1 gene, 83 and $56 \%$ of plants survived up to the five- to six-leaf stage. Moreover, not a single wild-type plant reached the five-leaf stage at 0.6 or $0.8 \% \mathrm{NaCl}$, while some transgenic plants survived for up to 30 days ( $\mathrm{Li}$ et al. 2010). Likewise, transgenic maize lines had more grain yield per plant than the respective control hybrids due to more grain per row and higher 1000-gr weight under saline conditions ( $\mathrm{Li}$ et al. 2010). Efficient compartmentalization of sodium in vacuoles of cells of transgenic maize improved not only salt resistance but also grain productivity in saline fields ( $\mathrm{Li}$ et al. 2010). Moreover, potassium concentration in leaves and roots of transgenic maize lines was much higher than that of wild- type plants (Li et al. 2010). By using the Flippase recombination enzyme P/Flippase recognition target-based marker elimination system to eliminate the als gene, Li et al. (2010) produced marker-free salt-tolerant transgenic maize to improve the bio-safety of the environment.

The overexpression of AtNHXI resulted in enhanced salt resistance in transgenic maize (Yin et al. 2004). The generated transgenic maize plants expressed the $O_{S N H X 1}$ from rice which accumulated high biomass in the presence of $200 \mathrm{mM}$ $\mathrm{NaCl}$ (Chen et al. 2007).

In conclusion, transgenic approach is quite effective for improving salt resistance in maize. For instance, maize genotypes with external genes producing vacuolar $\mathrm{Na}^{+} / \mathrm{H}^{+}$ antiporter and betaine aldehyde dehydrogenase etc. performed well under salt stress.

\subsection{Arbuscular mycorrhizal fungi}

Arbuscular mycorrhizal fungi penetrate the cortical cells of roots in a vascular plant forming unique structures, arbuscules, and vesicles. Arbuscular mycorrhizal fungi help plants to capture nutrients such as phosphorus, sulfur, nitrogen, and micronutrients from the soil. Root colonization by arbuscular mycorrhizal fungi can induce major changes in the relative abundance of major groups of organic solutes (Sheng et al. 2011). Arbuscular mycorrhizal fungi colonization of plant roots is reduced by salt stress, indicating that salinity suppresses the formation of arbuscular mycorrhiza (Sheng et al. 2008).

Salt resistance in maize improved with arbuscular mycorrhizal fungi colonization and symbiosis (Feng et al. 2002). 
Although salinity can negatively affect arbuscular mycorrhizal fungi, many reports have shown improved growth and performance of mycorrhizal plants under salt stress conditions. This improvement has been correlated with host plant nutrition, improved potassium/sodium ratios in plant tissues, and better osmotic adjustment. Arbuscular mycorrhizal fungi also improved photosynthetic and water use efficiencies under salt stress. At the molecular level, arbuscular mycorrhizal symbiosis regulates the expression of plant genes involved in the biosynthesis of proline, genes encoding aquaporins, and genes encoding late embryogenesis abundant proteins with chaperone activity (Porcel et al. 2012). In fact, in maize, there are more than 30 different aquaporin genes (Chaumont et al. 2001), and the regulation of these genes allows mycorrhizal plants to maintain better water status in their tissues. Gene expression patterns suggest that mycorrhizal plants are less strained by salt stress than non-mycorrhizal plants (Porcel et al. 2012).

In summary, arbuscular mycorrhizal fungi colonization and symbiosis improve salt resistance in maize due to better nutrient availability, increased potassium/sodium ratios in plant tissues, and better osmotic adjustment

\subsection{Plant-growth-promoting rhizobacteria}

Soil bacteria applied through seed inoculation, which colonize plant roots and enhance plant growth and/or resistance against abiotic stresses, are called plant-growth-promoting rhizobacteria. Increased ethylene in plants is directly related to the concentration of 1-aminocyclopropane-1-carboxylate, produced under stress conditions, in plant tissues (Machackov et al. 1997). Recently, it was discovered that several plant-growth-promoting rhizobacteria promote plant growth by lowering endogenous ethylene synthesis in roots through 1-aminocyclopropane-1-carboxylate deaminase activity (Glick et al. 1998). When 1-aminocyclopropane-1carboxylate deaminase-containing plant-growth-promoting rhizobacteria are bound to the developing seedling, they can act as a sink for 1-aminocyclopropane-1-carboxylate ensuring that the ethylene level does not become elevated to the point where root growth is impaired (Grichko et al. 2000). By reducing ethylene and facilitating the formation of longer roots, these bacteria may enhance seedling survival during the first few days after sowing (Glick et al. 1998). Soil microorganisms that produce 1-aminocyclopropane-1-carboxylate deaminase promote plant growth by sequestering and cleaving plant-produced 1-aminocyclopropane-1-carboxylate, thereby lowering ethylene levels in the plant (Penrose et al. 2001). Plant ethylene levels are regulated by 1-aminocyclopropane1-carboxylate deaminase, a key enzyme present in plantgrowth-promoting rhizobacteria, by metabolizing its precursor 1-aminocyclopropane-1-carboxylate into $\alpha$-ketobutyrate and ammonia. Inoculation of plants under salinity stress with plant-growth-promoting rhizobacteria having 1aminocyclopropane-1-carboxylate deaminase activity mitigates the inhibitory effects of salinity on root growth by lowering the ethylene concentration in the plant (Nadeem et al. 2010; Zafar-ul-Hye et al. 2014). Inoculation of rhizobacteria with 1-aminocyclopropane-1-carboxylate deaminase activity is effective in promoting plant growth under salt stress by lowering ethylene or 1-aminocyclopropane-1-carboxylate accumulation, which at higher levels can inhibit root and shoot growth (Kausar and Shahzad 2006). Negative effects of stressinduced ethylene could be partially eliminated by inoculation with 1-aminocyclopropane-1-carboxylate deaminasecontaining rhizobacteria (Nadeem et al. 2006). In a field study, Nadeem et al. (2009) reported that rhizobacterial strains, particularly Pseudomonas and Enterobacter spp., significantly promoted the growth and yield of maize under salt stress.

Inoculation enhanced salt resistance by reducing sodium concentration, which improved the potassium/sodium ratio and calcium level in maize tissues. This may further enhance water flow which significantly improves dry matter production (Hamdia et al. 2004). The inoculation of maize with Azospirillum under a salt-stressed environment significantly decreased proline concentration. The comparatively high salt resistance of maize, particularly the salt-sensitive cultivar, significantly changed the selectivity of potassium, calcium, and sodium. Azospirillum inoculation reduced the rate of sodium uptake and increased the uptake of major cations particularly calcium and potassium (Table 3; Hamdia et al. 2004). RojasTapias et al. (2012) demonstrated that inoculation with Azotobacter chroococcum strains C5 and C9 protected plants against the inhibitory effects of $\mathrm{NaCl}$ by improving sodium exclusion and potassium uptake in maize, thereby increasing the potassium/sodium ratio. Polyphenol and chlorophyll contents were enhanced by inoculation with strains C5 and C9.

In crux, inoculation of maize seeds with 1aminocyclopropane-1-carboxylate deaminase-producing bacteria improves the salt resistance of maize by reducing ethylene production and triggering the formation of longer roots, whereas inoculation with Azospirillum reduces the rate of sodium uptake and increases the uptake of major cations particularly calcium and potassium, thus improving salt resistance in maize.

4.6 Exogenous application of hormones and osmoprotectants

Exogenous application of various plant growth regulators and osmoprotectants is widely used to neutralize the damaging effects of salt stress on plants. Externally applied plant hormones and osmoprotectants like auxins, gibberellins, cytokinins, abscisic acid, brassinolids, polyamines, and salicylic acid have the potential to ameliorate toxic effects of salt stress in maize with elevated osmotic adjustment to maintain turgor, improve nutrient uptake, accumulate antioxidants, 
Table 3 Influence of plant-growth-promoting rhizobacteria containing 1-aminocyclopropane-1-carboxylate deaminase on salt resistance of maize

\begin{tabular}{|c|c|c|}
\hline Bacteria/transgenic plants with ACC deaminase & Plant response & References \\
\hline $\begin{array}{l}\text { Pseudomonas syringae, Pseudomonas } \\
\text { chlororaphis, Pseudomonas bathycetes, } \\
\text { Enterobacter aerogenes, Pseudomonas } \\
\text { fluorescence }\end{array}$ & $\begin{array}{l}\text { Inoculation improved growth under high levels of salinity. Relative } \\
\text { water content, chlorophyll content, and potassium/sodium ratio } \\
\text { enhanced by inoculation over control. In another study by the } \\
\text { same authors, inoculation improved growth, yield, and nutrition } \\
\text { of maize plants under saline field conditions }\end{array}$ & Nadeem et al. $(2007,2009)$ \\
\hline Azotobacter strains $\mathrm{C} 5$ and $\mathrm{C} 9$ & $\begin{array}{l}\text { Sodium exclusion and potassium uptake in maize, thereby increasing } \\
\text { potassium/sodium ratio. Enhanced polyphenol and chlorophyll } \\
\text { contents }\end{array}$ & Rojas-Tapias et al. (2012) \\
\hline $\begin{array}{l}\text { Plant-growth-promoting rhizobacteria having 1- } \\
\text { aminocyclopropane-1-carboxylate deaminase }\end{array}$ & $\begin{array}{l}\text { Significant increases in root-shoot length, root-shoot fresh and dry } \\
\text { weights, and chlorophyll pigments observed at electrical } \\
\text { conductivity } 10 \mathrm{dS} \mathrm{m}^{-1} \text { compared to uninoculated control }\end{array}$ & Nadeem et al. (2006) \\
\hline $\begin{array}{l}\text { Pseudomonas putida biotype A, Pseudomonas } \\
\text { fluorescens biotype A }\end{array}$ & $\begin{array}{l}\text { Plants demonstrated good root-shoot length against salinity stress } \\
\text { under gnotobiotic conditions }\end{array}$ & Kausar and Shahzad (2006) \\
\hline Azotobacter chroococcum strains C5 and C9 & $\begin{array}{l}\text { Improved sodium exclusion and potassium uptake in maize, thereby } \\
\text { increasing potassium/sodium ratio. Enhanced polyphenol and } \\
\text { chlorophyll contents }\end{array}$ & Rojas-Tapias et al. (2012) \\
\hline $\begin{array}{l}\text { Rhizobium strain Thal-8 chickpea nodulating } \\
\text { Pseudomonas } \mathrm{sp} .54 \mathrm{RB}\end{array}$ & $\begin{array}{l}\text { Reduced electrolyte leakage and osmotic potential, increased } \\
\text { osmoregulant (proline) production, maintenance of relative water } \\
\text { content in leaves, and selective uptake of potassium ions. } \\
\text { Increased total uptake of potassium and calcium }\end{array}$ & Bano and Fatima (2009) \\
\hline Bacillus megaterium & $\begin{array}{l}\text { Increased root hydraulic conductance in inoculated plants which } \\
\text { correlated with more plasma membrane type two (PIP2) } \\
\text { aquaporin in roots under salt-stressed conditions. More } Z m P I P 1 ; 1 \\
\text { protein under salt-stressed conditions in inoculated leaves }\end{array}$ & Marulanda et al. (2010) \\
\hline Azospirillum lipoferum strain Z4/1 & $\begin{array}{l}\text { Azospirillum inoculation markedly altered sodium, potassium, and } \\
\text { calcium selectivity. Azospirillum restricted sodium uptake and } \\
\text { enhanced potassium and calcium uptake. Azospirillum inoculation } \\
\text { stimulated nitrate reductase and nitrogenase activity in both shoots } \\
\text { and roots of both cultivars }\end{array}$ & Hamdia et al. (2004) \\
\hline
\end{tabular}

and detoxify reactive oxygen species, thereby maintaining membrane and enzyme stability (He et al. 1991; Hussein et al. 2007; Gunes et al. 2007; Kaya et al. 2010).

Salt stress substantially reduced total biomass, chlorophyll $\mathrm{a}$ and $\mathrm{b}$ contents, grain yield, and relative water contents accompanied by elevated electrolyte leakage; application of both kinetin and indole acetic acid on foliage individually nullified the damaging effects of $\mathrm{NaCl}$ stress while, in combination, had no effect on salinity resistance in maize plants (Kaya et al. 2010). Moreover, salinity increased leaf sodium concentration in maize at the expense of calcium and potassium, while foliar application of kinetin and indole acetic acid rectified these effects and increased calcium and potassium contents in leaves. Therefore, foliar application of kinetin and indole acetic acid at $2 \mathrm{mM}$ has the potential to counteract the adverse effects of salinity on maize growth and productivity due to increased uptake of essential nutrients and better membrane permeability (Kaya et al. 2010). Previously, Darra and Saxena (1973) reported that foliar indole acetic acid application improved the uptake of essential nutrients along with a notable decline in sodium uptake leading to better growth and yield of maize under salt stress.

Salicylic acid is another important secondary metabolite that induces salinity resistance in plants by regulating several physiological processes through signaling. Maize plants exposed to $40 \mathrm{mM} \mathrm{NaCl}$ reduced plant dry biomass, while those with exogenously applied salicylic acid increased dry biomass in both saline and non-saline environments, but the effect was more pronounced in the saline environment (Gunes et al. 2007). Likewise, salt stress increased membrane permeability in maize leaves as a consequence of elevated lipid peroxidation, measured in terms of malondialdehyde content, but salicylic acid application reduced membrane permeability and decreased lipid peroxidation in the saline environment (Gunes et al. 2007).

In another study, a maize crop irrigated with 4000 ppm saline water reduced leaf area and stem, leaf, and wholeplant dry weights by $53.18,57.29,47.43$, and $51.43 \%$, respectively, compared with the control, while 200-ppm foliar application of salicylic acid rectified the deleterious effects of salinity and improved plant height; number and area of green leaves; stem diameter; and stem, leaf, and wholeplant dry weights. Moreover, salicylic acid application enhanced proline accumulation and amino acid contents such as arginine, lycine, serine, and glutamic acid under stress conditions (Hussein et al. 2007). Salicylic acid application also helped to overcome salinity-induced nutrient imbalance in maize (Hussein et al. 2007). Nitrogen uptake decreased, 
but phosphorus uptake increased in maize under salinity stress, and salicylic acid reversed it with considerable reductions in sodium and chloride accumulation. Furthermore, iron, manganese, zinc, and copper contents increased with salinity and salicylic acid application further aggravated their uptake except for zinc (Gunes et al. 2007). Likewise, brassinosteroid application enabled maize seedling growth to recover from the effects of salinity (He et al. 1991).

Foliar spray of hydrogen peroxide effectively minimized salinity-induced effects by increasing the activities of catalase, guaiacol peroxidase, ascorbate peroxidase, and superoxide dismutase, with catalase being the most responsive. Increased catalase activity appears to be linked to gene expression regulation and lower malondialdehyde levels (Gondim et al. 2012).

Hydrogel polymers can also be used as soil conditioners to improve plant growth due to their ability to swell in water and release the absorbed water to plant roots and their involvement in partitioning, binding, and release of essential plant nutrients particularly under salt stress. El Sayed (2011) observed severe reductions in plant height, root extension, root and shoot biomass, harvest index, leaf area, photosynthesis, mitotic division, and productivity (both grain and straw yield per pot) in salinity-stressed maize in a sandy soil, while insertion of the hydrogel polymer in sand rectified the damaging effects of salinity and substantially improved all of the above-mentioned traits.

Tuna et al. (2008) evaluated the combined effects of salt stress and gibberellins on plant growth and the nutritional status of maize. Salt stress reduced total dry matter, chlorophyll content, and relative water content but increased proline accumulation, superoxide dismutase, peroxidase and polyphenol oxidase activities, and electrolyte leakage. Gibberellin treatments overcame to varying extents the adverse effects of $\mathrm{NaCl}$ stress on the above physiological parameters. Gibberellins reduced enzyme activities in salt-stressed plants. Salt stress reduced some macronutrient and micronutrient concentrations, but exogenous application of gibberellins increased these to control levels. Foliar application of gibberellins counteracted some of the adverse effects of $\mathrm{NaCl}$ salinity with the accumulation of proline which maintained membrane permeability and increased macronutrient and micronutrient levels.

Pretreatment by addition of $1 \mu \mathrm{M}$ hydrogen peroxide to a hydroponic solution for 2 days induced increased salt resistance during subsequent exposure to salt stress. This was evidenced by plant growth, lipid peroxidation, and antioxidative enzyme measurements. In both leaves and roots, the variations in lipid peroxidation and antioxidative enzyme (superoxide dismutase, ascorbate peroxidase, guaiacol peroxidase, glutathione reductase, and catalase) activities of both acclimated and unacclimated plants suggest that differences in antioxidative enzyme activities may, at least in part, explain the increased resistance of acclimated plants to salt stress and that hydrogen peroxide metabolism is involved as a signal in the process of maize salt acclimation (de Azevedo Neto et al. 2005). In maize, exogenously applied glycine betaine improved growth, leaf water content, net photosynthesis, and the apparent quantum yield of photosynthesis in salt-stressed plants (Yang and $\mathrm{Lu}$ 2005). The glycine betaine application, however, did not affect maximum efficiency of photosystem II photochemistry. The improvement in photosynthesis of saltstressed maize plants by glycine betaine application was suggested to be associated with improvements in stomatal conductance and actual photosystem II efficiency (Yang and Lu 2005). Foliar application of glycine betaine to low or nonaccumulating plants helped to improve plant growth under salinity stress (Yang and Lu 2005). It was also observed that glycine betaine-treated plants under salinity stress had significantly reduced sodium and increased potassium concentrations in shoots compared with untreated plants. Hence, glycine betaine may help in salinity resistance through its role in signal transduction and ion homeostasis. Exogenous application of glycine betaine to low-accumulating or nonaccumulating plants may help to reduce adverse effects of environmental stresses (Yang and $\mathrm{Lu}$ 2005).

To summarize, exogenous application of plant hormones and osmoprotectants like auxins, gibberellins, cytokinins, abscisic acid, brassinolids, polyamines, salicylic acid, and proline may also help to improve maize performance under salt stress. Application of these substances helps in osmotic adjustment, nutrient uptake, and the antioxidant defense system.

\subsection{Seed priming and nutrient management}

Suboptimal crop stands due to poor and erratic seed germination are a challenge for profitable crop production in saline areas. Salt stress substantially reduces and delays germination in maize (Farsiani and Ghobadi 2009) due to salinity-induced osmotic stress and toxic effects of sodium and chloride ions on germinating seeds (Hasegawa et al. 2000; Khaje-Hosseini et al. 2003). Seed priming has the potential to improve maize germination under saline conditions. Hydropriming under salt stress improved final germination percentage, germination index, seedling vigor index, and seedling length in maize, proving its potential as a seed invigoration technique for improved maize performance under saline conditions (Janmohammadi et al. 2008).

Soaking maize grains in water improved their germination rate under saline conditions (Ashraf and Rauf 2001). In addition, the authors demonstrated that sodium, potassium, and calcium concentrations increased significantly in all parts of a germinating seed primed with sodium chloride, potassium chloride, or calcium chloride, respectively. Seeds primed with calcium chloride had the highest chloride accumulation in all parts of the germinating seed, followed by seeds treated with 
sodium chloride and potassium chloride. Most of the calcium was retained in the seed and mesocotyl, thus restricting its transport to plumules and radicles. Ashraf and Rauf (2001) investigated seed halopriming with distilled water, sodium chloride, potassium chloride, and calcium chloride and found that, while all of the salt agents were effective at mitigating the adversities of salinity on maize germination, priming with calcium chloride was the most effective. Hormonal priming with chloroethylphosphonic acid, an ethylene releaser, enhanced maize seedling biomass under salt stress (Table 4; Carvalho et al. 2011).

Hydropriming significantly improved germination and seedling growth presented as final germination percentage, germination index, seedling vigor index, and seedling length in stressed and non-stressed maize (Janmohammadi et al. 2008). Presowing treatments with 28 -homobrassinolide further enhanced the activities of antioxidative enzymes in addition to lowering lipid peroxidation and increasing protein concentration, thus suggesting that 28 -homobrassinolide can alleviate oxidative stress in salt-treated maize plants (Arora et al. 2008). Other priming agents for improving growth or seed yield under saline conditions and not just germination of the pretreated seed include ascorbic acid, thiamin, and pyridoxine (Ahmed-Hamad and Monsaly 1998). Khodary (2004) found that $0.1-\mathrm{mM}$ salicylic acid application to plants under saline conditions enhanced growth and development.

Imbalanced nutrition due to impaired uptake and transport of essential plant nutrients such as nitrogen, calcium, potassium, magnesium, iron, and zinc under salt stress is well reported in maize leading to diminished plant growth and productivity (Karimi et al. 2005; Gunes et al. 2007; Turan et al. 2010; Kaya et al. 2010; Shahzad et al. 2012; Qu et al. 2012). Application of these essential plant elements has the potential to counteract the effects of salinity stress on maize productivity. Potassium application enhanced productivity in all maize cultivars by improving yield-related traits under saline conditions which confirms the role of potassium in the salinity resistance of maize (Maqsood et al. 2008). Likewise, significant elevations in leaf area index and crop growth rate of maize after potassium application in saline fields have been reported (Akram et al. 2010b) and are linked to continued water uptake and turgor maintenance, as potassium plays a key role in osmoregulation (Akram et al. 2010b). Other positive effects of potassium application are improved water relations and mineral nutrition, in terms of reduced sodium uptake (Akram et al. 2010b). Likewise, greater reductions in potassium, calcium, and magnesium contents in both leaves and roots of maize occurred with the combined stresses rather than with only the salt stress or only potassium deficiency. Salinity enhanced both sodium and chloride accumulation in leaves and roots and potassium scarcity further aggravated their buildup. Moreover, potassium/sodium, calcium/sodium, and magnesium/sodium ratios declined in both leaves and roots with larger reductions when combined rather than with individual stresses (Qu et al. 2012). Iron foliar application improved the nutritional status of maize seedlings grown under salinity stress (Salama et al. 1996).

Under salinity stress, maize growth is affected by nitrogen deficiency as a result of antagonistic effects of chloride ions with nitrate ions (Shahzad et al. 2012); hence, nitrogen application can significantly improve maize performance in saline conditions. Nitrogen application at $120 \mathrm{~kg} \mathrm{ha}^{-1}$ counteracted the damaging effects of salinity and notably improved growth, yield, and nitrogen uptake under salt stress (Gadalla et al. 2007). In another study, nitrogen application above the recommended level for non-saline soils substantially increased

Table 4 Influence of seed priming on the performance of maize under saline conditions

\begin{tabular}{|c|c|c|c|}
\hline Presowing technique & Nature of priming agent & Attribute/s which improved & References \\
\hline Hydropriming & - & Germination & Ashraf and Rauf (2001) \\
\hline Hormonal priming & $\begin{array}{l}\text { Ascorbic acid, thiamin, and } \\
\text { pyridoxine }\end{array}$ & Growth, grain yield & $\begin{array}{l}\text { Ahmed-Hamad and Monsaly } \\
\text { (1998) }\end{array}$ \\
\hline Hormonal priming & Salicylic acid & Growth, photosynthesis, carbohydrate metabolism & Khodary (2004) \\
\hline Matripriming & Sand priming & $\begin{array}{l}\text { Shoot height, seedling fresh and dry weights, soluble } \\
\text { sugars, peroxidase, and catalase activities }\end{array}$ & Zhang et al. (2007) \\
\hline Hormonal priming & $\begin{array}{l}\text { Chloroethylphosphonic acid, an } \\
\text { ethylene releaser }\end{array}$ & Biomass & Carvalho et al. (2011) \\
\hline Hydropriming & - & Germination, early seedling growth & Janmohammadi et al. (2008) \\
\hline Hormonal priming & 28-homobrassinolide & $\begin{array}{l}\text { Protein concentration, antioxidative enzyme activities } \\
\text { (decreased lipid peroxidation) }\end{array}$ & Arora et al. (2008) \\
\hline Hormonal priming & Hydrogen peroxide & $\begin{array}{l}\text { Seed germination percentage, activities of ascorbate } \\
\text { peroxidase, catalase, and guaiacol peroxidase }\end{array}$ & Gondim et al. (2010) \\
\hline Halopriming & $\mathrm{NaCl}$ & Earlier emergence and germination rate, plant height, yield & Bakht et al. (2011) \\
\hline Hormonal priming & Ethylene & Biomass & Carvalho et al. (2011) \\
\hline Halopriming & $\mathrm{NaCl}$ & Shoot dry weight and length, leaf number and area, chlorophyll & Farahbakhsh and Saiid (2011) \\
\hline
\end{tabular}


physiological traits such as leaf area index, crop growth rate, net assimilation rate, and all yield components in salt-stressed maize compared with the control (Akram et al. 2010c). While nitrogen nutrition is important in crop production under salt stress, the nitrogen source is also important. For instance, nitrogen application through ammonium increased catalase, glutathione reductase, and glutathione-S-transferase activities in maize, while peroxide dismutase and superoxide dismutase activities decreased (Rios-Gonzalez et al. 2002).

In conclusion, seed priming with sodium, calcium, and potassium salts is an effective approach to improve maize germination under salt stress. As nitrogen and potash deficiency is observed in salt-affected soils, application of nitrogenous and potash fertilizers may help to improve maize performance in saline conditions.

\section{Conclusions}

Salt stress is a major obstacle for ensuring global food security. Research on developing salt resistance in maize is diverse. Salinity imposes osmotic stress and ionic toxicity to plants which have adverse effects on stand establishment, growth, and development. Salt stress disturbs the activities of cytosolic enzymes and may cause nutritional disorders and oxidative damage, all of which drastically reduce maize yield. The development of salt-resistant plants through conventional breeding and genetic engineering has shown that conventional breeding has been more successful in this regard. Nonetheless, expected future advances in transformation technology like RNAi, transposon insertional knockouts for candidate stress-resistant genes, and comprehensive knowledge of signaling pathways are predicted to generate salt-resistant maize plants in coming years. Integration of mass screening and breeding, marker-assisted selection, exogenous application of hormones and osmoprotectants for seeds or growing plants, and cellular-based stress signaling and ion homeostasis mechanisms into a functional paradigm for the whole plant may help to improve salt resistance in maize.

\section{References}

Abdullah Z, Khan MA, Flowers TJ (2001) Causes of sterility in seed set of rice under salinity stress. J Agron Crop Sci 187:25-32. doi:10. 1046/j.1439-037X.2001.00500.x

Ahmed-Hamad AM, Monsaly HM (1998) Seed soaking pre-sowing in vitamins versus the adverse effects of $\mathrm{NaCl}$ salinity on photosynthesis and some related activities of maize and sunflower plants. In: Proceedings of the $11^{\text {th }}$ International Congress on Photosynthesis, Vol. IV, pp. 2617-2620. Kluwer Academic, Budapest, Hungary. August, 17-22
Akram M, Malik MA, Ashraf MY, Saleem MF, Hussain M (2007) Competetive seedling growth and $\mathrm{K}^{+} \mathrm{Na}^{+}$ratio in different maize (Zea mays L.) hybrids under salinity stress. Pak J Bot 39:2553-2563

Akram M, Ashraf MY, Ahmad R, Rafiq M, Ahmad I, Iqbal J (2010a) Allometry and yield components of maize (Zea mays L.) hybrids to various potassium levels under saline conditions. Arch Biol Sci Belgrade 62:1053-1061. doi:10.2298/ABS1004053A

Akram M, Ashraf MY, Ahmad R, Waraich EA, Iqbal J, Mohsan M (2010b) Screening for salt tolerance in maize (Zea mays L.) hybrids at an early seedling stage. Pak J Bot 42:141-154

Akram M, Ashraf MY, Waraich EA, Hussain M, Hussain N, Mallahi AR (2010c) Performance of autumn planted maize (Zea mays L.) hybrids at various nitrogen levels under salt affected soils. Soil Environ 29:23-32

Alberico GL, Cramer GR (1993) Is the salt tolerance of maize related to sodium exclusion? I. Preliminary screening of seven cultivars. J Plant Nutr 16:2289-2303. doi:10.1080/01904169309364687

Arora N, Bhardwaj R, Sharma P, Arora HK (2008) 28-Homobrassinolide alleviates oxidative stress in salt treated maize (Zea mays L.) plants. Braz J Plant Physiol 20:153-157

Ashraf M, Foolad MR (2005) Pre-sowing seed treatment-a shotgun approach to improve germination growth and crop yield under saline and none-saline conditions. Adv Agron 88:223-271. doi:10.1016/ S0065-2113(05)88006-X

Ashraf M, Rauf H (2001) Inducing salt tolerance in maize (Zea mays L.) through seed priming with chloride salts: growth and ion transport at early growth stages. Acta Physiol Plant 23:407-414. doi:10.1007/ s11738-001-0050-9

Aspinall D (1986) Metabolic effects of water and salinity stress in relation to expansion of the leaf surface. Aust J Plant Physiol 13:59-73. doi: 10.1071/PP9860059

Atanassova L, Stojanov I, Pissarska M, Valkova C (1997) Salt stressinduced changes of cytokinins in maize and pea plants RNA. Bulg J Plant Physiol 23:33-39

Bakht J, Shafi M, Jamal Y, Sher H (2011) Response of maize (Zea mays L.) to seed priming with $\mathrm{NaCl}$ and salinity stress. Span J Agric Res 9:252-261

Bano A, Fatima M (2009) Salt tolerance in Zea mays (L.) following inoculation with Rhizobium and Pseudomonas. Biol Fertil Soils 45:405-413. doi:10.1007/s00374-008-0344-9

Barlow EWR (1986) Water relations of expanding leaves. Aust J Plant Physiol 13:45-58. doi:10.1071/PP9860045

Beltagi MS (2008) Molecular responses of Bt transgenic corn (Zea mays L.) plants to salt $(\mathrm{NaCl})$ stress. Aust J Crop Sci 2:57-63

Benes SE, Aragües R, Grattan SR, Austin RB (1996) Foliar and root absorption of $\mathrm{Na}^{+}$and $\mathrm{Cl}^{-}$in maize and barley: implications for salt tolerance screening and the use of saline sprinkler irrigation. Plant Soil 180:75-86. doi:10.1007/BF00015413

Blumwald E (2000) Sodium transport and salt tolerance in plants. Curr Opin Cell Biol 12:431-434. doi:10.1016/S0955-0674(00)00112-5

Botelia MA, Martinez V, Pardines J, Cerda A (1997) Salinity induced potassium deficiency in maize plants. J Plant Physiol 150:200-205. doi:10.1016/S0176-1617(97)80203-9

Burr SJ, Fry SC (2009) Extracellular cross-linking of maize arabinoxylans by oxidation of feruloyl esters to form oligoferuloyl esters and etherlike bonds. Plant J 58:554-567. doi:10.1111/j.1365-313x.2009. 03800.x

Carpita NC (1996) Structure and biogenesis of the cell walls of grasses. Annu Rev Plant Physiol Plant Mol Biol 47:445-476. doi:10.1146/ annurev.arplant.47.1.445

Carvalho RF, Piotto FA, Schmidt D, Peters LP, Monteiro CC, Azevedo RA (2011) Seed priming with hormones does not alleviate induced oxidative stress in maize seedlings subjected to salt stress. Sci Agric 68:598-602

Cerda A, Pardines J, Botelia MA, Martinez V (1995) Effect of potassium on growth, water relations, and the inorganic and organic solute 
contents for two maize cultivars grown under saline conditions. J Plant Nutr 18:839-851. doi:10.1080/01904169509364942

Cha-um S, Kirdmanee C (2009) Effect of salt stress on proline accumulation, photosynthetic ability and growth characters in two maize cultivars. Pak J Bot 41:87-98

Chaumont F, Barrieu F, Wojcik E, Chrispeels MJ, Jung R (2001) Aquaporins constitute a large and highly divergent protein family in maize. Plant Physiol 125:1206-1215. doi:10.1104/pp. 125.3. 1206

Chen M, Chen Q-J, Niu X-G, Zhang R, Lin H-Q, Xu C-Y, Wang X-C, Wang G-Y, Chen J (2007) Expression of OsNHX1 gene in maize confers salt tolerance and promotes plant growth in the field. Plant Soil Environ 53:490-498

Chinnusamy V, Jagendorf A, Zhu JK (2005) Understanding and improving salt tolerance in plants. Crop Sci 45:437-448. doi:10.2135/ cropsci2005.0437

Cosgrove DJ (2000) Loosening of plant cell walls by expansins. Nature 407:321-326. doi:10.1038/35030000

Cramer GR, Epstein E, Lauchli A (1988) Kinetics of root elongation of maize in response to short term exposure to $\mathrm{NaCl}$ and elevated calcium concentration. J Exp Bot 39:1513-1522. doi:10.1093/jxb/ 39.11.1513

Cramer GR, Alberico GJ, Schmidt C (1994) Salt tolerance is not associated with the sodium accumulation of two maize hybrids. Funct Plant Biol 21:675-692. doi:10.1071/PP9940675

Darra BL, Saxena SN (1973) Role of IAA on the mineral composition of maize crop under various osmotic stressed conditions. Plant Soil 38: 657-661. doi:10.1007/BF00010704

Davenport R, James RA, Zakrisson-Plogander A, Tester M, Munns R (2005) Control of sodium transport in durum wheat. Plant Physiol 137:807-818. doi:10.1104/pp. 104.057307

de Azevedo Neto AD, Tabosa JN (2000) Salt stress in maize seedlings: II. Distribution of cationic macronutrients and its relation with sodium. Rev Bras Eng Agric Amb 4:165-171. doi:10.1590/S141543662000000200005

de Azevedo Neto AD, Prisco JT, Enéas-Filho J, de Lacerda CF, Silva JV, da Costa PHA, Gomes-Filho E (2004) Effects of salt stress on plant growth, stomatal response and solute accumulation of different maize genotypes. Braz J Plant Physiol 16:31-38

de Azevedo Neto AD, Prisco JT, Enéas-Filhob J, Medeirosb J-VR, Gomes-Filho E (2005) Hydrogen peroxide pre-treatment induces salt-stress acclimation in maize plants. J Plant Physiol 162:1114 1122. doi:10.1016/j.jplph.2005.01.007

de Azevedo Neto AD, Prisco JT, Eneas J, de Abreu CEB, Gomes-Filho E (2006) Effect of salt stress on antioxidative enzymes and lipid peroxidation in leaves and roots of salt-tolerant and salt sensitive maize varieties. Environ Exp Bot 56:87-94. doi:10.1016/j.envexpbot. 2005.01.008

De Costa W, Zorb C, Hartung W, Schubert S (2007) Salt resistance is determined by osmotic adjustment and abscisic acid in newly developed maize hybrids in the first phase of salt stress. Physiol Plant 131: 311-321. doi:10.1111/j.1399-3054.2007.00962.x

De Souza IRP, MacAdam JW (1998) A transient increase in apoplastic peroxidase activity precedes decrease in elongation rate of B73 maize (Zea mays L.) leaf blades. Physiol Plant 104:556-562. doi: 10.1111/j.1399-3054.1998.1040406.x

De Souza IRP, MacAdam JW (2001) Gibberellic acid and dwarfism effects on the growth dynamics of B73 maize (Zea mays L.) leaf blades: a transient increase in apoplastic peroxidase activity precedes cessation of cell elongation. J Exp Bot 52:1673-1682. doi: 10.1093/jexbot/52.361.1673

Devi SR, Prasad MNV (1996) Ferulic acid mediated changes in oxidative enzymes of maize seedlings: implications in growth. Biol Plant 38: 387-395. doi:10.1007/BF02896668

Eker S, Comertpay G, Konuskan O, Ulger AC, Ozturk L, Cakmak I (2006) Effect of salinity stress on dry matter production and ion accumulation in hybrids maize varieties. Turk J Agric For 30: 365-373

El Sayed HESA (2011) Influence of salinity stress on growth parameters, photosynthetic activity and cytological studies of Zea mays, L. plant using hydrogel polymer. Agric Biol J N Am 2:907-920. doi:10. 5251/abjna.2011.2.6.907.920

E1-Bassiouny HMS, Bekheta MA (2001) Role of putrescine on growth, regulation of stomatal aperture, ionic contents and yield by two wheat cultivars under salinity stress. Egypt J Physiol Sci 2-3: 239-258

Encina A, Fry SC (2005) Oxidative coupling of a feruloyl-arabinoxylan trisaccharide (FAXX) in the walls of living maize cells requires endogenous hydrogen peroxide and is controlled by a low-Mr apoplastic inhibitor. Planta 223:77-89. doi:10.1007/s00425-0050033-y

Erdei L, Szegletes Z, Barabas K, Pestenacz A (1996) Responses in polyamine titer under osmotic and salt stress in sorghum and maize seedlings. J Plant Physiol 147:599-603. doi:10.1016/S01761617(96)80052-6

FAO (2005) Global network on integrated soil management for sustainable use of salt-affected soils. FAO Land and Plant Nutrition Management Service, Rome, Italy, http://www.fao.org/ag/agl/agl1/ spush

Farahbakhsh H, Saiid MS (2011) Effect of seed priming with $\mathrm{NaCl}$ on maize germination under different saline conditions. Afr J Agric Res 6:6095-6099

Farooq M, Bramley H, Palta JA, Siddique KHM (2011) Heat stress in wheat during reproductive and grain filling phases. Crit Rev Plant Sci 30:491-507. doi:10.1080/073552689.2011.615687

Farooq M, Hussain M, Siddique KHM (2014) Drought stress in wheat during flowering and grain-filling periods. Crit Rev Plant Sci 33: 331-349. doi:10.1080/073552689.2014.875291

Farsiani A, Ghobadi ME (2009) Effects of PEG and NaCl stress on two cultivars of corn (Zea mays L.) at germination and early seedling stages. World Acad Sci Eng Technol 57:382-385

Feng G, Zhang FS, Li XL, Tian CY, Tang C, Rengel Z (2002) Improved tolerance of maize plants to salt stress by arbuscular mycorrhiza is related to higher accumulation of soluble sugars in roots. Mycorrhiza 12:185-190. doi:10.1007/s00572-002-0170-0

Flowers TJ, Flowers SA (2005) Why does salinity pose such a difficult problem for plant breeders? Agric Water Manag 78:15-24. doi:10. 1016/j.agwat.2005.04.015

Flowers TJ, Yeo A (1995) Breeding for salinity resistance in crops. Where next? Aust J Plant Physiol 22:875-884. doi:10.1071/PP9950875

Fortmeier R, Schubert S (1995) Salt tolerance of maize (Zea mays L.): the role of sodium exclusion. Plant Cell Environ 18:1041-1047. doi:10. 1111/j.1365-3040.1995.tb00615.x

Gadalla AM, Hamdy A, Galal YGM, Aziz HAA, Mohamed MAA (2007) Evaluation of maize growth under salinity stress and N application strategies using stable nitrogen isotope. Proc Afr Crop Sci Conf 8:1553-1562

Geilfus C-M, Zörb C, Mühling KH (2010) Salt stress differentially affects growth-mediating $\beta$-expansins in resistant and sensitive maize (Zea mays L.). Plant Physiol Biochem 48:993-998. doi:10.1016/j.plaphy. 2010.09.011

Giaveno CD, Ribeiro RV, Souza GM, de Oliveira RF (2007) Screening of tropical maize for salt stress tolerance. Crop Breed Appl Biotechnol 7:304-313

Gill SS, Tuteja N (2010) Reactive oxygen species and antioxidant machinery in abiotic stress tolerance in crop plants. Plant Physiol Biochem 48:909-930. doi:10.1016/j.plaphy.2010.08.016

Glick BR, Penrose DM, Li J (1998) A model for the lowering of plant ethylene concentrations by plant growth promoting bacteria. J Theor Biol 190:63-68. doi:10.1006/jtbi.1997.0532

Goldsworthy (1994) Calcium and salinity. Appl Biol 4:1-6 
Gondim FA, Gomes-Filho E, Lacerda CF, Prisco JT, Neto ADA, Marques EC (2010) Pretreatment with $\mathrm{H}_{2} \mathrm{O}_{2}$ in maize seeds: effects on germination and seedling acclimation to salt stress. Braz J Plant Physiol 22:103-112

Gondim FA, Gomes-Filho E, Costa JH, Alencar NLM, Prisco JT (2012) Catalase plays a key role in salt stress acclimation induced by hydrogen peroxide pretreatment in maize. Plant Physiol Biochem 56: 62-71. doi:10.1016/j.plaphy.2012.04.012

Gong XL, Liu C, Zhou M, Luo LY, Wang L, Wang Y, Hong MM, Cai JW, Gong SJ, Hong FS (2011) Oxidative damages of maize seedlings caused by combined stress of potassium deficiency and salt stress. Plant Soil 340:443-452. doi:10.1007/s11104-010-0616-7

Gosal SS, Wani SH, Kang MS (2009) Biotechnology and drought tolerance. J Crop Improv 23:19-54. doi:10.1080/15427520802418251

Grichko VP, Filey B, Glick BR (2000) Increased ability of transgenic plant expressing the bacterial enzyme 1-aminocylopropane-1carboxylic acid deaminase to accumulate $\mathrm{Cd}, \mathrm{Co}, \mathrm{Cu}, \mathrm{Ni}, \mathrm{Pb}$ and Zn. J Biotechnol 81:45-53. doi:10.1016/S0168-1656(00)00270-4

Gunes A, Inal A, Alpaslam M, Erslan F, Bagsi EG, Cicek N (2007) Salicylic acid induced changes on some physiological parameters symptomatic for oxidative stress and mineral nutrition in maize ( $Z e a$ mays L.) grown under salinity. J Plant Physiol 164:728-736. doi:10. 1016/j.jplph.2005.12.009

Hager A (2003) Role of the plasma membrane $\mathrm{H}^{+}$-ATPase in auxininduced elongation growth: historical and new aspects. J Plant Res 116:483-505. doi:10.1007/s10265-003-0110-x

Hajibagheri MA, Harvey DMR, Flowers TJ (1987) Quantitative distribution within the root cells of salt-sensitive and salt-tolerant maize varieties. New Phytol 105:367-379. doi:10.1111/j.1469-8137. 1987.tb00874.x

Hajibagheri MA, Yeo AR, Fwwers TJ, Collins JC (1989) Salinity resistance in Zea mays: fluxes of potassium, sodium and chloride, cytoplasmic concentrations and microsomal membrane lipids. Plant Cell Environ 12:753-757. doi:10.1111/j.1365-30401989.tb01635.x

Hamdia MAE, Shaddad MAK, Doaa MM (2004) Mechanisms of salt tolerance and interactive effects of Azospirillum brasilense inoculation on maize cultivars grown under salt stress conditions. Plant Growth Regul 44:165-174. doi:10.1023/B:GROW.0000049414. 03099.9b

Hasegawa PM, Bressan RA, Zhu JK, Bohnert HJ (2000) Plant cellular and molecular response to high salinity. Annu Rev Plant Physiol Plant Mol Biol 51:463-499 doi:1040-2519/00/0601-0463

Hatzig S, Hanstein S, Schubert S (2010) Apoplast acidification is not a necessary determinant for the resistance of maize in the first phase of salt stress. J Plant Nutr Soil Sci 173:559-562. doi:10.1002/jpln. 201000117

He RY, Wang GJ, Wang XS (1991) Effect of brassinolide on growth and chilling resistance of maize seedlings. In: Cutler HG, Yokota T, Adam G (eds) Brassinosteroids. Am Chem Soc, Washington DC, pp 220-230

He SJ, Dong W, Li HF, Gu DM, Chen SY, Tian WZ (1999) Production and salt tolerance identification of transgenic maize with betaine aldehyde dehydrogenase gene. High Technol Lett 2:50-52

Hichem H, Mounir D, Naceur EA (2009) Differential responses of two maize (Zea mays L.) varieties to salt stress: changes on polyphenols composition of foliage and oxidative damages. Ind Crops Prod 30: 144-151. doi:10.1016/j.indcrop.2009.03.003

Hiyane R, Hiyane S, Tang AC, Boyer JS (2010) Sucrose feeding reverses shade-induced kernel losses in maize. Ann Bot 106:395-403. doi: 10.1093/aob/mcq132

Hu Y, Burucs Z, Tucher SV, Schmidhalter U (2007) Short-term effects of drought and salinity on mineral nutrient distribution along growing leaves of maize seedlings. Environ Exp Bot 60:268-275. doi:10. 1016/j.envexpbot.2006.11.003
Hussain M, Park HW, Farooq M, Jabran H, Lee D-J (2013) Morphological and physiological basis of salt resistance in different rice genotypes. Int J Agric Biol 15:113-118

Hussein MM, Balbaa LK, Gaballah MS (2007) Salicylic acid and salinity effects on growth of maize plants. Res J Agric Biol Sci 3:321-328

Hutsch BW, Saqib M, Osthushenrich T, Schubert S (2014) Invertase activity limits grain yield of maize under salt stress. J Plant Nutr Soil Sci 177:278-286. doi:10.1002/jpln.201300345

Isla R, Aragues R (2010) Yield and plant ion concentrations in maize (Zea mays $\mathrm{L}$.) subject to diurnal and nocturnal saline sprinkler irrigations. Field Crops Res 116:175-183. doi:10.1016/j.fcr.2009.12.008

Jafar MZ, Farooq M, Cheema MA, Afzal I, Basra SMA, Wahid MA, Aziz T, Shahid M (2012) Improving the performance of wheat by seed priming under saline conditions. J Agron Crop Sci 198:38-45. doi: 10.1111/j.1439-037x.2011.00487.x

Janmohammadi M, Dezfuli PM, Sharifzadeh F (2008) Seed invigoration techniques to improve germination and early growth of inbred line of maize under salinity and drought stress. Gen Appl Plant Physiol $34: 215-226$

Kanai R, Edwards GE (1999) The biochemistry of $C_{4}$ photosynthesis. In: Sage RF, Monson RK (eds) $\mathrm{C}_{4}$ plant biology. Academic Press, San Diego, pp 49-87

Karimi G, Ghorbanli M, Heidari H, Khavarinejad RA, Assareh MH (2005) The effects of $\mathrm{NaCl}$ on growth, water relations, osmolytes and ion content in Kochia prostrate. Biol Plant 49:301-304. doi:10. 1007/s10535-005-1304-y

Kausar R, Shahzad SM (2006) Effect of ACC-deaminase containing rhizobacteria on growth promotion of maize under salinity stress. J Agri Soc Sci 2:216-218

Kaya C, Tuna AL, Okant AM (2010) Effect of foliar applied kinetin and indole acetic acid on maize plants grown under saline conditions. Turk J Agric For 34:529-538. doi:10.3906/tar-0906-173

Kaya C, Ashraf M, Dikilitas M, Tuna AL (2013) Alleviation of salt stressinduced adverse effects on maize plants by exogenous application of indoleacetic acid (IAA) and inorganic nutrients - a field trial. Aust J Crop Sci 7:249-254

Khaje-Hosseini M, Powell AA, Bingham IJ (2003) The interaction between salinity stress and seed vigour during germination of soybean seeds. Seed Sci Technol 31:715-725

Khan AA, Rao SA, McNilly TM (2003) Assessment of salinity tolerance based upon seedling root growth response functions in maize (Zea mays L.). Euphytica 131:81-89. doi:10.1023/A:1023054706489

Khodary SEA (2004) Effect of salicylic acid on the growth, photosynthesis and carbohydrate metabolism in salt-stressed maize plants. Int $\mathbf{J}$ Agric Biol 6:5-8

Li B, Li N, Duan X, Wei A, Yang A, Zhang J (2010) Generation of marker-free transgenic maize with improved salt tolerance using the FLP/FRT recombination system. J Biotechnol 145:206-213. doi:10.1016/j.jbiotec.2009.11.010

Lindsay SE, Fry SC (2008) Control of diferulate formation in dicotyledonous and gramineous cell-suspension cultures. Planta 227:439452. doi:10.1007/s00425-007-0630-Z

Liu Y, Wang G, Liu J, Peng X, Xie Y, Dai J, Guo S, Zhang F (1999) Transfer of E. coli gutD gene into maize and regeneration of salttolerant transgenic plants. Sci China Ser C 42:90-95. doi:10.1007/ BF002881753

Lohaus G, Hussmann M, Pennewiss K, Schneider H, Zhu JJ, Sattelmacher B (2000) Solute balance of a maize (Zea mays L.) source leaf as affected by salt treatment with special emphasis on phloem re-translocation and ion leaching. J Exp Bot 51:1721-1732. doi:10.1093/jexbot/51.351.1721

Maas EV, Hoffman GJ (1977) Crop salt tolerance - current assessment. J Irrig Drain Div ASCE 103:115-134

Maas EV, Hoffman GJ, Chaba GD, Poss JA, Shannon MC (1983) Salt sensitivity of corn at various growth stages. Irrig Sci 4:45-57. doi: 10.1007/BF00285556 
Machackov C, Dewitte N, Van Onckelen W (1997) Diurnal fluctuation in ethylene formation in Chenopodiun rubrum. Plant Physiol 113:981985. doi:10.1104/pp. 113.3.981

Mansour MMF, Salama KHA, Ali FZM, Abou Hadid AF (2005) Cell and plant responses to $\mathrm{NaCl}$ in Zea mays cultivars differing in salt tolerance. Gen Appl Plant Physiol 31:29-41

Maqsood T, Akhtar J, Farooq MR, Haq MA, Saqib ZA (2008) Biochemical attributes of salt tolerant and salt sensitive maize cultivars to salinity and potassium nutrition. Pak J Agric Sci 45:1-5

Marulanda A, Azcón R, Chaumont F, Ruiz-Lozano JM, Aroca R (2010) Regulation of plasma membrane aquaporins by inoculation with a Bacillus megaterium strain in maize (Zea mays L.) plants under unstressed and salt-stressed conditions. Planta 232:533-543. doi: 10.1007/s00425-010-1196-8

Menezes-Benavente L, Kernodle SP, Margis-Pinheiro M, Scandalios JG (2004) Salt-induced antioxidant metabolism defenses in maize (Zea mays L.) seedlings. Redox Rep 9:29-36. doi:10.1179/ 135100004225003888

Mittler R (2002) Oxidative stress, antioxidants and stress tolerance. Trends Plant Sci 7:405-410. doi:10.1016/S1360-1385(02)02312-9

Mühling KH, Läuchli A (2002) Effect of salt stress on growth and cation compartmentation in leaves of two plant species differing in salt tolerance. J Plant Physiol 159:137-146. doi:10.1078/0176-161700701

Munns R (1993) Physiological processes limiting growth in saline soils: some dogmas and hypotheses. Plant Cell Environ 16:15-24. doi:10. 1111/j.1365-3040.1993.tb00840.x

Munns R (2002) Comparative physiology of salt and water stress. Plant Cell Environ 25:239-250. doi:10.1046/j.0016-8025.2001.00808.x

Munns R (2005) Genes and salt tolerance: bringing them together. New Phytol 167:645-663. doi:10.1111/j.1469-8137.2005.01487.x

Munns R, Sharp RE (1993) Involvement of abscisic acid in controlling plant growth in soils of low water potential. Aust J Plant Physiol 20: 425-437. doi:10.1071/PP9930425

Munns R, Tester M (2008) Mechanisms of salinity tolerance. Ann Rev Plant Biol 59:651-681. doi:10.1146/annrev.arplant.59.032607. 092911

Munns R, James RA, Läuchli A (2006) Approaches to increasing the salt tolerance of wheat and other cereals. J Exp Bot 57:1025-1043. doi: 10.1093/jxb/erj100

Nadeem SM, Hussain I, Naveed M, Asghar HN, Zahir ZA, Arshad M (2006) Performance of plant growth promoting rhizobacteria containing ACC-deaminase activity for improving growth of maize under salt-stressed conditions. Pak J Agric Sci 43:114-121

Nadeem SM, Zahir ZA, Naveed M, Arshad M (2007) Preliminary investigations on inducing salt tolerance in maize through inoculation with rhizobacteria containing ACC deaminase activity. Can J Microbiol 53:1141-1149. doi:10.1139/w07-081

Nadeem SM, Zahir ZA, Naveed M, Arshad M (2009) Rhizobacteria containing ACC-deaminase confer salt tolerance in maize grown on salt-affected fields. Can J Microbiol 55:1302-1309. doi:10. 1139/w09-092

Nadeem SM, Zahir ZA, Naveed M, Ashraf M (2010) Microbial ACCdeaminase: prospects and applications for inducing salt tolerance in plants. Crit Rev Plant Sci 29:360-393. doi:10.1080/07352689.2010. 524518

Neubert AB, Zörb C, Schubert S (2005) Expression of vacuolar $\mathrm{Na}^{+} / \mathrm{H}^{+}$ antiporters $(Z m N H X)$ and $\mathrm{Na}^{+}$exclusion in roots of maize (Zea mays L.) genotypes with improved salt resistance In: Li CJ et al. (eds) Plant nutrition for food security, human health and environmental protection, Tsinghua University Press, Bejing, China, pp 544-545

Omoto E, Taniguchi M, Miyake H (2012) Adaptation responses in $\mathrm{C}_{4}$ photosynthesis of maize under salinity. J Plant Physiol 169:469477. doi:10.1016/j.jplph.2011.11.009

Paterniani E (1990) Maize breeding in tropics. Crit Rev Plant Sci 9:125154. doi:10.1080/07352689009382285
Penrose OW, Moffat BA, Glick BR (2001) Determination of ACC to assess the effect of ACC to assess the effect of ACC-deaminasecontaining bacteria on roots of canola seedlings. Can J Microbiol 47: 77-80. doi:10.1139/w00-128

Peterson TA, Nieman RH, Clark RA (1987) Nucleotide metabolism in salt-stressed Zea mays root tips. Plant Physiol 85:984-989. doi:10. 1104/pp. 85.4.984

Pitann B, Kranz T, Mühling KH (2009a) The apoplastic pH and its significance in adaptation to salinity in corn (Zea mays L.): comparison of fluorescence microscopy and $\mathrm{pH}$-sensitive microelectrodes. Plant Sci 176:497-504. doi:10.1016/j.plantsci.2009.01.002

Pitann B, Schubert S, Mühling KH (2009b) Decline in leaf growth under salt stress is due to an inhibition of $\mathrm{H}^{+}$pumping activity and increase in apoplastic pH of maize leaves. J Plant Nutr Soil Sci 172:535-543. doi:10.1002/jpln.200800349

Pitann B, Zörb C, Mühling KH (2009c) Comparative proteome analysis of maize (Zea mays L.) expansins under salinity. J Plant Nutr Soil Sci 172:75-77. doi:10.1002/jpln.200800265

Pitann B, Mohamed A-K, Neubert AB, Schubert S (2013) Tonoplast $\mathrm{Na}+\mathrm{H}+$ antiporters of newly developed maize (Zea mays) hybrids contribute to salt resistance during the second phase of salt stress. J Plant Nutr Soil Sci 176:148-156. doi:10.1002/jpln.201200597

Porcel R, Aroca R, Ruiz-Lozano JM (2012) Salinity stress alleviation using arbuscular mycorrhizal fungi. A review. Agron Sustain Dev 32:181-200. doi:10.1007/s13593-011-0029-x

Qu C, Liu C, Gong X, Li C, Hong M, Wang L, Hong F (2012) Impairment of maize seedling photosynthesis caused by a combination of potassium deficiency and salt stress. Environ Exp Bot 75: 134-141. doi:10.1016/j.envexpbot.2011.08.019

Quan R, Shang M, Zhang H, Zhao Y, Zhang J (2004) Improved chilling tolerance by transformation with betaA gene for the enhancement of glycinebetaine synthesis in maize. Plant Sci 166:141-149. doi:10. 1016/j.plantsci.2003.08.018

Quintero JM, Fournier JM, Benlloch M (2007) $\mathrm{Na}^{+}$accumulation in shoot is related to water transport in $\mathrm{K}^{+}$-starved sunflower plants but not in plants with a normal $\mathrm{K}^{+}$status. J Plant Physiol 164:6067. doi:10.1016/j.jplph.2005.10.010

Rengasamy P (2006) World salinization with emphasis on Australia. J Exp Bot 57:1017-1023. doi:10.1093/jxb/erj108

Rios-Gonzalez K, Erdei L, Lips SH (2002) The activity of antioxidant enzymes in maize and sunflower seedlings as affected by salinity and different nitrogen sources. Plant Sci 162:923-930. doi:10.1016/ S0168-9452(02)00040-7

Rodríguez AA, Maiale SJ, Menéndez AB, Ruiz OA (2009) Polyamine oxidase activity contributes to sustain maize leaf elongation under saline stress. J Exp Bot 60:4249-4262. doi:10.1093/jxb/erp255

Rodríguez-Kessler M, Alpuche-Solís AG, Ruiz OA, Jiménez-Bremont JF (2006) Effect of salt stress on the regulation of maize (Zea mays L.) genes involved in polyamine biosynthesis. Plant Growth Regul 48: 175-185. doi:10.1007/s10725-005-5990-4

Rojas-Tapias D, Moreno-Galván A, Pardo-Díaz S, Obando M, Rivera D, Bonilla R (2012) Effect of inoculation with plant growthpromoting bacteria (PGPB) on amelioration of saline stress in maize (Zea mays). Appl Soil Ecol. doi:10.1016/j.apsoil.2012.01.006

Sairam RK, Tyagi A (2004) Physiology and molecular biology of salinity stress tolerance in plants. Curr Sci 86:407-421

Salama ZA, Shaaban MM, Abou El-Nour AEA (1996) Effect of iron foliar application on increasing tolerance of maize seedlings to saline irrigation water. Egypt J Appl Sci 11:169-175

Schubert S (2009) Advances in alleviating growth limitations of maize under salt stress. In: The Proceedings of the International Plant Nutrition Colloquium XVI, Department of Plant Sciences, UC Davis

Schubert S (2011) Salt resistance of crop plants: physiological characterization of a multigenic trait. In Hawkesford MJ, Barra-clough P 
(eds) The molecular and physiological basis of nutrient use efficiency in crops. Wiley, Inc., pp. 443-455

Schubert S, Läuchli A (1990) Sodium exclusion mechanism at the root surface of 2 maize cultivars. Plant Soil 123:205-209. doi:10.1007/ BF00011269

Schubert S, Neubert A, Schierholt A, Sumer A, Zorb C (2009) Development of salt resistant maize hybrids: the combination of physiological strategies using conventional breeding methods. Plant Sci 177:196-202. doi:10.1016/j.plantsci.2009.05.011

Serraj R, Sinclair TR (2002) Osmolyte accumulation: can it really help increase crop yield under drought conditions? Plant Cell Environ 25: 333-341. doi:10.1046/j.1365-3040.2002.0075.x

Shahzad M, Witzel K, Zorb C, Muhling KH (2012) Growth-related changes in subcellular ion patterns in maize leaves (Zea mays L.) under salt stress. J Agron Crop Sci 198:46-56. doi:10.1111/j.1439037X.2011.00487.X

Shannon MC, Grieve CM, Francois LE (1994) Whole plant response to salinity. In: Wilkinson RE (ed) Plant-environment interactions. Dekker, New York, pp 199-244

Sheng M, Tang M, Chan H, Yang B, Zhang F, Huang Y (2008) Influence of arbuscular mycorrhizae on photosynthesis and water status of maize plants under salt stress. Mycorrhiza 18:287-296. doi:10. 1007/s00572-008-0180-7

Sheng M, Tang M, Zhang F, Huang Y (2011) Influence of arbuscular mycorrhiza on organic solutes in maize leaves under salt stress. Mycorrhiza 21:423-430. doi:10.1007/s00572-010-0353-2

Spanswick RM (1981) Electrogenic ion pumps. Annu Rev Plant Physiol 32:267-289. doi:10.1146/annurev.pp. 32.060181.001411

Sümer A, Zörb C, Yan F, Schubert S (2004) Evidence of sodium toxicity for the vegetative growth of maize (Zea mays L.) during the first phase of salt stress. J Appl Bot 78:135-139

Szalai G, Janda T (2009) Effect of salt stress on the salicylic acid synthesis in young maize (Zea mays L.) plants. J Agron Crop Sci 195:165171. doi:10.1111/j.1439-037x.2008.00352.x

Tamas L, Huttova J, Mistrik I (2001) Impact of aluminium, $\mathrm{NaCl}$ and growth retardant tetcyclacis on growth and protein composition of maize roots. Biologia 56:441-448

Tuna AL, Kaya C, Dikilitas M, Higgs D (2008) The combined effects of gibberellic acid and salinity on some antioxidant enzyme activities, plant growth parameters and nutritional status in maize plants. Environ Exp Bot 62:1-9. doi:10.1016/j.envexpbot.2007.06.007

Turan MA, Elkarim AHA, Taban N, Taban S (2010) Effect of salt stress on growth and ion distribution and accumulation in shoot and root of maize plant. Afr J Agric Res 5:584-588

Uddin MN, Hanstein S, Leubner R, Schubert S (2013) Leaf Cell-wall components as influenced in the first phase of salt stress in three maize (Zea mays L.) hybrids differing in salt resistance. J Agron Crop Sci 199:405-415. doi:10.1111/jac.12031

Van Volkenburgh E, Boyer JS (1985) Inhibitory effects of water deficit on maize leaf elongation. Plant Physiol 77:190-194. doi:10.1104/pp. 77.1 .190

Volkmar KM, Hu Y, Steppuhn H (1998) Physiological responses of plants to salinity: a review. Can J Plant Sci 78:19-27. doi:10.4141/P97-020

Wakeel A, Sümer A, Hanstein S, Yan F, Schubert S (2011a) In vitro effect of $\mathrm{Na}^{+} / \mathrm{K}^{+}$ratios on the hydrolytic and pumping activity of the plasma membrane $\mathrm{H}^{+}$-ATPase from maize (Zea mays L.) and sugar beet (Beta vulgaris L.) shoot. Plant Physiol Biochem 49:341-345. doi:10.1016/j.plaphy.2011.01.006

Wakeel A, Farooq M, Qadir M, Schubert S (2011b) Potassium substitution by sodium in plants. Crit Rev Plant Sci 30:401-413. doi:10. 1080/07352689.2011.587728

Wu Y, Meeley RB, Cosgrove DJ (2001) Analysis and expression of the $\alpha$-expansin and $\beta$-expansin gene families in maize. Plant Physiol 126:222-232. doi:10.1104/pp. 126.1.222

Wu W, Su Q, Xia XY, Wang Y, Luan YS, An LJ (2008) The Suaeda liaotungensis kitag betaine aldehyde dehydrogenase gene improves salt tolerance of transgenic maize mediated with minimum linear length of DNA fragment. Euphytica 159:17-25. doi:10.1007/ s10681-007-9451-1

Yang X, Lu C (2005) Photosynthesis is improved by exogenous glycinebetaine in salt-stressed maize plants. Physiol Plant 124: 343-352. doi:10.1111/j.1399-3054.2005.00518.x

Yasmeen A, Basra SMA, Farooq M, Rehman H, Hussain N, Athar HR (2013) Exogenous application of moringa leaf extract modulates the antioxidant enzyme system to improve wheat performance under saline conditions. Plant Growth Regul 69:225-233. doi:10.1007/ s10725-012-9764-5

Yeo AR, Kramer D, Lauchli A, Gullasch J (1977) Ion distribution in saltstressed mature Zea mays roots in relation to ultrastructure and retention of sodium. J Exp Bot 28:17-29. doi:10.1093/jxb/28.1.17

Yin XY, Yang AF, Zhang KW, Zhang JR (2004) Production and analysis of transgenic maize with improved salt tolerance by the introduction of AtNHX1 gene. Acta Bot Sin 46:854-861

Younis ME, El-Shahaby OA, Nematalla MM, El-Basrawisy ZM (2003) Kinetin alleviates the influence of waterlogging and salinity on growth and affects the production of plant growth regulators in Vigna sinensis and Zea mays. Agronomie 23:277-285

Zafar-ul-Hye M, Farooq HM, Zahir ZA, Hussain M, Hussain A (2014) Application of ACC-deaminase containing rhizobacteria with fertilizer improves maize production under drought and salinity stress. Int J Agric Biol 16:591-596

Zhang CF, Hu J, Lou J, Zhang Y, Hu WM (2007) Sand priming in relation to physiological changes in seed germination and seedling growth of waxy maize under high-salt stress. Seed Sci Technol 35:733-738

Zheng J, Zhao J, Zhang J, Fu J, Gou M, Dong Z, Hou W, Huang Q, Wang $\mathrm{G}$ (2006) Comparative expression profiles of maize genes from a water stress-specific cDNA macroarray in response to high salinity, cold or abscisic acid. Plant Sci 170:1125-1132. doi:10.1016/j. plantsci.2006.01.019

Zhu JK (2001) Plant salt tolerance. Trends Plant Sci 6:66-71. doi:10. 1016/S1360-1385(00)01838-0

Zörb C, Schmitt S, Neeb A, Karl S, Linder M, Schubert S (2004) The biochemical reaction of maize (Zea mays L.) to salt stress is characterized by a mitigation of symptoms and not by a specific adaptation. Plant Sci 167:91-100. doi:10.1016/j.plantsci.2004.03.004

Zörb C, Stracke B, Tramnitz B, Denter D, Sümer A, Mühling KH, Yan F, Schubert $\mathrm{S}$ (2005) Does $\mathrm{H}^{+}$pumping by plasmalemma ATPase limit leaf growth of maize (Zea mays) during the first phase of salt stress. J Plant Nutr Soil Sci 168:550-557. doi:10.1002/jpln.200520503 